\title{
The Lost History of Delegation at the Founding
}

Christine Chabot

Loyola University Chicago, cchabot@luc.edu

Follow this and additional works at: https://digitalcommons.law.uga.edu/glr

Part of the Administrative Law Commons, Legal History Commons, and the Supreme Court of the United States Commons

\section{Recommended Citation}

Chabot, Christine (2021) "The Lost History of Delegation at the Founding," Georgia Law Review. Vol. 56: No. 1, Article 3.

Available at: https://digitalcommons.law.uga.edu/glr/vol56/iss1/3

This Article is brought to you for free and open access by Digital Commons @ University of Georgia School of Law. It has been accepted for inclusion in Georgia Law Review by an authorized editor of Digital Commons @ University of Georgia School of Law. Please share how you have benefited from this access For more information, please contact tstriepe@uga.edu. 


\section{The Lost History of Delegation at the Founding}

\section{Cover Page Footnote}

Associate Director for Regulation, Institute for Consumer Antitrust Studies, and Distinguished Scholar in Residence, Loyola University Chicago School of Law. Thanks to Kevin Arlyck, Emily Bremer, Craig Green, Hal Krent, Nick Parrillo, Matthew Sag, Josh Sarnoff, Jamelle Sharpe, Barry Sullivan, Spencer Waller, and participants at the AALS Annual Meeting, New Voices in Administrative Law and Legislation, Constitutional Law Colloquium, and Chicagoland Junior Scholars Conference for helpful comments. Thanks also to Anna Kenneally and Madeleine Morris for outstanding research assistance and the Loyola Law School Faculty Research Support Fund for financial assistance. All errors are my own. 


\title{
THE LOST HISTORY OF DELEGATION AT THE FOUNDING
}

\author{
Christine Kexel Chabot*
}

The new Supreme Court is poised to bring the administrative state to a grinding halt. Five Justices have endorsed Justice Gorsuch's dissent in Gundy v. United States-an opinion that threatens to invalidate countless regulatory statutes in which Congress has delegated significant policymaking authority to the Executive Branch. Justice Gorsuch claimed that the "text and history" of the Constitution required the Court to replace a longstanding constitutional doctrine that permits broad delegations with a more restrictive one. But the supposedly originalist arguments advanced by Justice Gorsuch and like-minded scholars run counter to the understandings of delegation that prevailed in the Founding Era. This Article brings to light previously overlooked historical evidence of debates over the constitutionality of delegation in the First Congress, as well as an in-depth analysis of important policy decisions that the First Congress subsequently delegated to the Executive Branch. It shows that Alexander Hamilton, James Madison, and the First Congress all approved of legislation that delegated some of our nation's most consequential policy decisions to the Executive Branch.

Delegation was the First Congress's solution to what was arguably the greatest problem facing our fledgling Republic: a potentially insurmountable national debt. Alexander Hamilton proposed a debt restructuring plan that would delegate Congress's Article I, Section 8 power to "borrow Money," and James Madison and other members of the First Congress

\footnotetext{
*Associate Director for Regulation, Institute for Consumer Antitrust Studies, and Distinguished Scholar in Residence, Loyola University Chicago School of Law. Thanks to Kevin Arlyck, Emily Bremer, Craig Green, Hal Krent, Nick Parrillo, Matthew Sag, Josh Sarnoff, Jamelle Sharpe, Barry Sullivan, Spencer Waller, and participants at the AALS Annual Meeting, New Voices in Administrative Law and Legislation, Constitutional Law Colloquium, and Chicagoland Junior Scholars Conference for helpful comments. Thanks also to Anna Kenneally and Madeleine Morris for outstanding research assistance and the Loyola Law School Faculty Research Support Fund for financial assistance. All errors are my own.
} 
debated this delegation before concluding that it was constitutional. The resulting legislation delegated decisions regarding borrowing and payment policies of the utmost importance to the national economy to President Washington and executive officers serving on the Sinking Fund Commission. Delegation was also the First Congress's solution to a protracted dispute over national patent rights to revolutionary steam power technology. Although the Intellectual Property Clause empowered Congress to resolve inventors' competing petitions for exclusive patent rights, the First Congress declined to do so and instead passed a barebones patent act that required executive officers to determine fundamental legal parameters for granting patents. The first U.S. debt and patent laws implicated some of the most significant policy questions facing our nation, and Hamilton, Madison, and the First Congress never understood the Constitution to prohibit Congress from delegating these questions. The doctrine recognized in the Founding Era provides no reason for the Court to overhaul Congress's constitutionally prescribed role or set aside over eighty years of precedent. 


\section{TABLE OF CONTENTS}

I. INTRODUCTION ........................................................ 85

II. THE LEGAL LANDSCAPE ........................................... 91

A. LEGISLATIVE POWERS (WHAT ARTICLE I SAYS AND

LEAVES UNSAID) .............................................. 91

B. PRECEDENT: IMPORTANT SUBJECTS AND INTELLIGIBLE

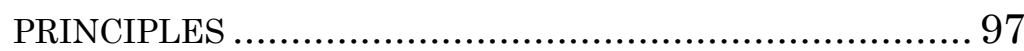

C. THE MANY FACES OF NONDELEGATION ORIGINALISM 101

III. The FIRST CONGRESS'S DELEGATION OF IMPORTANT QUESTIONS

A. THE FIRST U.S. LAWS ON BORROWING AND REPAYMENT

OF DEBT

1. Alexander Hamilton's Proposal.

2. The First Congress Rejected a Constitutional Objection to the Delegation of Borrowing Power

3. The Borrowing Legislation Delegated Broad Discretion to Determine Important Terms of Loans....

4. The Sinking Fund Legislation Delegated Key Monetary Policy Decisions

5. Congress Continued Granting the Executive Broad Discretion to Pay Debt and Borrow Funds for "Public Purposes". 134

B. THE FIRST U.S. PATENT LAW .................................. 136

1. Congress Required the Patent Board to Determine "Causes of a Very Great Magnitude"

2. The Patent Board Created Its Own Procedure to Address Conflicting Claims to Steamboat Technology 
Georgia Law Review, Vol. 56, No. 1 [2021], Art. 3

84

GEORGIA LAW REVIEW

[Vol. 56:81

IV. MAdison's “NeCESSitY” WAS Not THE Mother OF THE

IMPORTANT SUBJECTS DOCTRINE ................................... 147

V. The Historical Record Provides No OCCASION to OVERTURN PRECEDENT ...................................................... 153

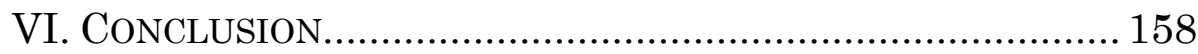




\section{INTRODUCTION}

The United States Congress delegates a wealth of policy decisions to the Executive Branch. Justice Gorsuch's dissent in Gundy $v$. United States asserts that this practice is unconstitutional, and his opinion casts doubt on countless regulatory statutes that delegate power to make "policy judgments" to executive officers. ${ }^{1}$ In Justice Gorsuch's view, such delegations unconstitutionally transfer an exclusively legislative power and exceed the prescribed executive role of finding "facts" and filling up the "details." $2 \mathrm{He}$ appears to have at least five votes to jettison the precedent condoning such broad delegations, ${ }^{3}$ and he claims that this doctrinal leap is justified by originalism and fidelity to separation of powers principles enshrined in the Constitution over 200 years ago. ${ }^{4}$ But as this Article demonstrates, it is Justice Gorsuch's argument, and not current doctrine, that is "at war" with the "text and history" of the Constitution. ${ }^{5}$

\footnotetext{
${ }^{1}$ Gundy v. United States, 139 S. Ct. 2116, 2141 (2019) (Gorsuch, J., joined by Roberts, C.J. \& Thomas, J., dissenting). According to Justice Gorsuch's dissent, the "Constitution demands" that "Congress, and not the Executive Branch, make the policy judgments" required by regulatory statutes. $I d$.

${ }^{2} I d$. at 2145 .

${ }^{3} I d$. at 2131 (Alito, J., concurring) (indicating willingness to "reconsider" the nondelegation doctrine in a future case); Paul v. United States, 140 S. Ct. 342, 342 (2019) (statement of Kavanaugh, J. respecting the denial of certiorari) (indicating support for a more rigorous nondelegation doctrine). The recent addition of another originalist, Justice Amy Coney Barrett, may yield yet another vote in favor of Justice Gorsuch's position. Amy Coney Barrett Confirmed to US Supreme Court, BBC (Oct. 27, 2020), https://www.bbc.com/news/election-us2020-54700307.

${ }^{4}$ Gundy, 139 S. Ct. at 2131 (Gorsuch, J., dissenting) ("The Constitution promises that only the people's elected representatives may adopt new federal laws restricting liberty."); see also DAvid Schoenbrod, Power Without Responsibility: How CONGREss ABuses the People Through DeLEGATION 31 (1993) ("[E]arly legislative practice seemed to accord with the theory of the Constitution"-or "nondelegation doctrine"-holding "that Congress rather than administrators shall make the law."); PHILIP HAMBURger, Is ADMINISTRATIVE LAW UNLAWFUL? 109 (2014) (asserting that Congress did not "systematically authorize[ the executive ... to exercise lawmaking will" until the late nineteenth and twentieth centuries).

${ }^{5}$ Gundy, 139 S. Ct. at 2131 (Gorsuch, J., dissenting). Justice Gorsuch's historical claims do not account for the materials presented in this Article, see id. at $2140 \mathrm{nn} .61-62$, and leading works cited by Justice Gorsuch emphasize structural arguments to the detriment of Founding-era history. See Harold J. Krent, Delegation and Its Discontents, 94 CoLuM. L. REV 710, 713 (1994) (reviewing SCHOENBROD, supra note 4) (arguing that Schoenbrod's arguments
} 
While previous debates over delegation traded only a few "scraps" of historical evidence, ${ }^{6}$ Justice Gorsuch's dissent in Gundy has inspired invaluable surveys of delegations in the Founding Era. These surveys reach different conclusions regarding Justice Gorsuch's proposed ban on delegations of "policy judgments,"7 which ostensibly encompass any binding "governmental act involving political discretion" 8 and exceed the Executive's circumscribed duty "to make factual findings." Recent scholarship has undermined originalist claims that the Constitution bars delegations involving only certain types of policy judgments: early legislation did not reflect a categorical ban on delegations of power to impose "coercive regulation of private rights and private conduct" any more than it reflected a ban on delegation of power over public rights. ${ }^{10}$ But this

possess "neither textual nor historical warrant"); Gary Lawson, Delegation and Original Meaning, 88 VA. L. REV. 327, 398 (2002) ("Enactments of early Congresses are particularly suspect [evidence of original meaning.]"); see also Adrian Vermeule, No, 93 TEX. L. REV. 1547, 1551 (2015) (reviewing HAMBURGER, supra note 4) (arguing that Hamburger's analysis ought to "spend far more time on the ordinary meaning of the text as of 1789").

${ }^{6}$ Larry Alexander \& Saikrishna Prakash, Reports of the Nondelegation Doctrine's Death Are Greatly Exaggerated, 70 U. CHI. L. REV. 1297, 1326 (2003) ("[We] have not systematically canvassed [Founding-era delegations.]"); Eric A. Posner \& Adrian Vermeule, Interring the Nondelegation Doctrine, 69 U. CHI. L. REV. 1721, 1732 (2002) ("We aren't aware of any comprehensive professional treatment of the history of the nondelegation doctrine . . ."); Cass R. Sunstein, Nondelegation Canons, 67 U. CHI. L. REV. 315, 322 (2000) ("[T] he practice of early congresses strongly suggests that broad grants of authority to the executive were not thought to be problematic.”). Other leading historical studies written before Gundy include the following: Jerry L. Mashaw, Creating the Administrative Constitution: The Lost ONE HUNDRED YEARS OF AMERICAN ADMINISTRATIVE LAW 34 (2012) (surveying Founding-era statutes establishing administrative agencies); Kenneth Culp Davis, A New Approach to Delegation, 36 U. CHI. L. REV. 713, 719-20 (1969) (addressing select Founding-era statutes); Michael B. Rappaport, The Selective Nondelegation Doctrine and the Line Item Veto: A New Approach to the Nondelegation Doctrine and Its Implications for Clinton v. City of New York, 76 TUL. L. REV. 265, 317-18, 365 n.341 (2001) (discussing Founding-era legislation on appropriations and borrowing); HAMBURGER, supra note 4, at 100-10, 198-201 (discussing concerns presented by early extraterritorial licensing regulations, presidential determinations regarding foreign nations, and patent laws).

${ }^{7}$ Gundy, 139 S. Ct. at 2141 (Gorsuch, J., dissenting).

8 Krent, supra note 5, at 713 n.14.

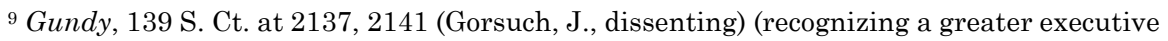
role in foreign affairs and other areas ostensibly committed to the President under Article II).

${ }^{10}$ Nicholas R. Parrillo, A Critical Assessment of the Originalist Case Against Administrative Regulatory Power: New Evidence from the Federal Tax on Private Real Estate in the 1790s, 130 YALE L.J. 1288, 1301-13 (2021) (analyzing delegation of "rulemaking power 
work leaves open other questions about the contours of an originalist nondelegation doctrine. Some scholars claim that there were no limits on any of the substantive powers that Congress could delegate to the Executive Branch, ${ }^{11}$ while other scholars contend that early Congresses sometimes delegated power to make policy judgments, just not important ones. ${ }^{12}$ The latter scholars provide continued reasons for the Court to abandon governing precedent and the longstanding requirement that power delegated to the Executive Branch be limited by an "intelligible principle." 13

This Article brings to light previously overlooked constitutional debates over delegation in the First Congress, as well as an in-depth analysis of important domestic policy decisions that Congress delegated to officers and agencies in the Executive Branch. ${ }^{14}$ This

under the 'direct tax' of 1798”); Kevin Arlyck, Delegation, Administration, and Improvisation, 97 Notre DAME L. REV. (forthcoming 2021) (manuscript at 6-8), https://scholarship.law.georgetown.edu/facpub/2366/ (examining how the Remission Act of 1790 delegated broad discretion to adjust statutory penalties imposed on private persons who violated customs laws). But see Michael B. Rappaport, A Two Tiered and Categorical Approach to the Nondelegation Doctrine, AM. ENTER. INST. (forthcoming) (manuscript at 2), https://papers.ssrn.com/sol3/papers.cfm?abstract_id=3710048 ("[T] $]$ he Constitution imposes a strict prohibition on" "rules that regulate citizens as to their private rights in the domestic sphere.”); Jennifer Mascott, Early Customs Laws and Delegation, 87 GEO. WASH. L. REV. 1388, 1391 (2019) (examining early customs laws in which Congress generated "the rules and policies imposing new limitations . . on private actors"); Aaron Gordon, Nondelegation, 12 N.Y.U. J.L. \& LIBERTY 718, 722 (2019) (arguing that "the Nondelegation Doctrine has a firm foundation in the Constitution's original meaning"); $c f$. Philip Hamburger, Delegating or Divesting? 115 Nw. U. L. REV. ONLINE 88, 106 (2020) (“[T] he Executive in the early years of the Republic did not make binding rules or adjudications.").

11 Julian Davis Mortenson \& Nicholas Bagley, Delegation at the Founding, 121 CoLUM. L. REV. 277, 280 (2021) ("[T]he Constitution at the Founding contained no discernable, legalized prohibition on delegations of legislative power ....”); accord Posner \& Vermeule, supra note 6, at 1723 ("[A] statutory grant of authority to the Executive Branch or other agents can never amount to a delegation of legislative power.").

12 Ilan Wurman, Nondelegation at the Founding, 130 YALE L.J. 1490, 1497 (2021) (favoring an "important subjects" theory of nondelegation); see also Gary Lawson, Mr. Gorsuch, Meet Mr. Marshall: A Private-Law Framework for the Public-Law Puzzle of Subdelegation, AM. ENTER. INST. (forthcoming) (manuscript at https://papers.ssrn.com/sol3/papers.cfm?abstract_id=3607159 (proposing "a distinction between 'important subjects' and matters of 'less interest'... as a test for identifying unconstitutional legislative subdelegations").

13 J.W. Hampton, Jr., \& Co. v. United States, 276 U.S. 394, 409 (1928).

${ }_{14}$ These regulatory functions are still executed by administrative agencies today. See Christine Kexel Chabot, Is the Federal Reserve Constitutional? An Originalist Argument for 
evidence establishes that the theory and practice of delegation in the Founding Era never reflected a particularly high constitutional bar. Early Congresses routinely delegated important policy decisions that required executive officers to go far beyond finding facts and filling up details. ${ }^{15}$ The limits early Congresses recognized for delegation were not exacting and generally required Congress to "establish the principle"16 (perhaps intelligibly) governing execution of the law. ${ }^{17}$ The restrained nondelegation doctrine identified by this Article does not support a significant shift to a requirement that Congress decide all important policy questions.

The First Congress considered and passed laws that delegated powers implicating two of the greatest challenges facing the nation: first, the need to provide a cost-effective means of repaying a potentially insurmountable debt; and second, the need to promote inventions that would facilitate industrialization. ${ }^{18}$ The express language of the Constitution designates these powers as "legislative" powers vested in Congress. In particular, Article I, Section 8 authorizes Congress to "pay the Debts," "borrow Money," and "promote the Progress of Science and useful Arts, by securing for limited Times to Authors and Inventors the exclusive Right to their respective Writings and Discoveries." 19

Congress debated the constitutionality of delegating its Article I, Section 8 powers during its initial efforts to establish the machinery of the new government. When confronting the pressing matter of

\footnotetext{
Independent Agencies, 96 NotRe DAME L. REV. 1, 47-52 (2020) (describing open market purchases implemented by the Sinking Fund Commission and today's Federal Reserve); Patent Basics, U.S. PAT. \& TRADEMARK OFF., https://www.uspto.gov/patents-gettingstarted/general-information-concerning-patents\#heading-1 (last modified July 1, 2021, 4:56 PM) (noting the USPTO's role in examining and granting patents).

15 See infra Part III.

163 AnNALs of Cong. 229 (1791) (statement of Rep. Sedgwick). The Annals of Congress were not compiled until 1834 and "did not include all previously published debates." Marion Tinling, Thomas Lloyd's Reports of the First Federal Congress, 18 WM. \& MARY Q. 519, 520 (1961). The first two volumes of the Annals of Congress were also published in two separate editions with different pagination. Id. at 520 n.2. References in this Article refer to the edition with the running head "History of Congress."

17 Though a "necessity" argument raised by James Madison supported more exacting requirements in one instance, 3 ANNALS OF CONG. 238-39 (1791), this argument does not support a broader ban on delegations of important policy questions. See infra Parts IV-V.

18 See infra Part III.

19 U.S. CONST. art. I, § 8.
} 
U.S. debt, Congress sought advice from the Secretary of the Treasury, Alexander Hamilton. He proposed legislation that would delegate power to repay the debt and borrow money. ${ }^{20}$ Despite constitutional objections to this delegation, James Madison and other members of the First Congress empowered President Washington to borrow up to $\$ 14$ million to refinance, purchase, and cover interest payments on U.S. debt. ${ }^{21}$ For 1790 this was an immense sum of money-on the scale of the $\$ 15$ million that the United States would spend to double its size in the Louisiana Purchase. ${ }^{22}$ In today's terms, this delegation would authorize the President to borrow over $\$ 1$ trillion. ${ }^{23}$

It is no surprise that Madison referred to the borrowing law as a delegation of "great trust" that left key terms of loans and "execution of one of the most important laws" to the President. ${ }^{24}$ Subsequent Congresses continued to award the President vast borrowing power and twice allowed him to borrow millions of dollars for "public purposes." 25 The First Congress also created the Sinking

\footnotetext{
20 Alexander Hamilton, Report Relative to a Provision for the Support of Public CREDIT (1790), https://founders.archives.gov/documents/Hamilton/01-06-02-0076-0002-0001. Unless otherwise noted, the historical papers cited in this study are drawn from the Founders Online collection compiled by the National Archive's National Historical Publications and Records Commission, available at https://founders.archives.gov/about [hereinafter FoUNDERS ONLINE].

${ }^{21}$ Act of Aug. 4, 1790, ch. 34, § 2, 1 Stat. 138, 139 (authorizing the President to borrow sums "not exceeding in the whole twelve million of dollars"); Act of Aug. 12, 1790, ch. 47, § 4, 1 Stat. 186, 187 (authorizing the President to borrow sums "not exceeding in the whole two millions of dollars"); see Lloyd's Notes, 19 May 1790, Debates in the House of Representatives, in XIII DOCUMENTARY HISTORY OF THE FIRST FEDERAL CONGRESS OF THE UNITED STATES OF AMERICA 1351 (Helen E. Veit, Charlene Bangs Bickford, Kenneth R. Bowling \& William Charles diGiacomantonio eds., 1994) [hereinafter Lloyd's Notes] (reporting constitutional debates over delegation of borrowing power); DAVID P. CURRIE, THE CONSTITUTION IN CONGRESS 73 n.143 (1997) (noting constitutional objections to delegation of borrowing power). Thomas Lloyd was "the favored reporter" who took shorthand notes on the debates in the House of Representatives. Tinling, supra note 16 at 519, 521.

22 The Louisiana Purchase, MonTICELLO, https://www.monticello.org/thomasjefferson/louisiana-lewis-clark/the-louisiana-purchase (last visited Oct. 14, 2021) (listing the price of the Louisiana Purchase as $\$ 15$ million).

${ }^{23}$ See infra note 248.

${ }^{24}$ Lloyd's Notes, supra note 21, at 1354 (parentheses omitted).

${ }_{25}$ Act of Mar. 20, 1794, ch. 8, 1 Stat. 345 (obsolete) (authorizing the President to borrow up to $\$ 1$ million); Act of Dec. 18,1794 , ch. 4,1 Stat. 404 (expired) (authorizing a loan of up to $\$ 2$ million "to be applied to such public purposes, as are authorized by law").
} 
Fund Commission, which was Alexander Hamilton's brainchild for supporting U.S. credit through open market purchases of debt held in the form of U.S. securities. ${ }^{26}$ This legislation required executive officers, including Alexander Hamilton, Thomas Jefferson, and other Commissioners, to determine the terms and amount of open market purchases that would bolster the value of U.S. securities while repaying the national debt. ${ }^{27}$ The United States' future credit and financial viability hinged on the policy decisions delegated to the Executive Branch in the borrowing and sinking fund legislation.

Debt legislation was not the only time that Congress delegated power to resolve important policy questions. Multiple inventors seeking exclusive rights to their discoveries petitioned Congress for patents, including those who battled over national patents for steamboat technology that was thought to reflect the start of "the automotive age." 28 In response, Congress departed from state legislatures' earlier practice of issuing patents through private laws. ${ }^{29}$ In the Patent Act of 1790, Congress delegated its Article I, Section 8 power to "promote the Progress of Science and useful Arts" to a Patent Board comprised of Secretary of State Thomas Jefferson, Attorney General Edmund Randolph, and Secretary of War Henry Knox. ${ }^{30}$ The Board could grant patents for any "sufficiently useful and important" inventions or discoveries, ${ }^{31}$ and no "yard stick was handed to these officers by Congress other than [this] undefined concept." ${ }_{22}$ The First Congress knowingly left the Board to establish fundamental legal parameters for granting patents.

This Article assesses the historical record on delegation as follows: Part II provides an overview of the nondelegation doctrine and the constitutional limits on Congress's ability to delegate its powers under Article I of the Constitution. Part III unearths

\footnotetext{
${ }^{26}$ See Hamilton, supra note 20 (proposing the Sinking Fund Commission).

27 See Act of Aug. 12, 1790, ch. 47, §4, 1 Stat. 186, 187.

${ }^{28}$ Frank D. Prager, The Steamboat Pioneers Before the Founding Fathers, 37 J. PAT. OfF. SoC'Y 486, 486 (1955).

${ }^{29}$ See Herbert Hovenkamp, The Emergence of Classical American Patent Law, 58 ARIZ. L. REV. 263, 267-68 (2016) (discussing early practices for issuing patents).

${ }^{30}$ U.S. ConsT. art. I, § 8, cl. 8; Act of Apr. 10, 1790, ch. 7, §1, 1 Stat. 109, 110 (repealed 1793).

${ }^{31}$ Act of Apr. 10, 1790, ch. 7, §1, 1 Stat. 109, 110 (repealed 1793).

${ }^{32}$ Frank D. Prager, Proposals for the Patent Act of 1790, 36 J. PAT. OFF. Soc’Y 157, 165 (1954).
} 
previously overlooked historical evidence surrounding the First Congress's delegations of power to the President and the executive officers who comprised the Patent Board and Sinking Fund Commission. The nondelegation doctrine recognized by the First Congress permitted delegation of some of our nation's most important policy questions to the Executive Branch. In Part IV, this Article reconciles the First Congress's broad delegations with the Second Congress's refusal to delegate power to establish post roads. In Parts V and VI, this Article concludes that fidelity to precedent and the historical record requires the Court to stand by the intelligible principle requirement.

When balancing constitutional objections against pressing needs to effectuate key legislative powers on repayment of debt and borrowing, Hamilton, Madison, and the First Congress all chose delegation. The First Congress handed off some of the Founding Era's most important questions on debt and intellectual property rights to executive officers. ${ }^{33}$ Even Thomas Jefferson never raised a constitutional objection to the powers delegated to him, despite his apparent dislike for both the financial policies effectuated by the Sinking Fund Commission and the heavy workload imposed on him by the Patent Board. ${ }^{34}$ None of these original originalists understood the Constitution to require that Congress resolve all important policy questions in legislation. If the Supreme Court requires Congress to take on this role now, the Court will create a brand new constitutional requirement that was never imagined by the Constitution's Framers.

\section{THE LEGAL LANDSCAPE}

\section{A. LEGISLATIVE POWERS (WHAT ARTICLE I SAYS AND LEAVES} UNSAID)

The nondelegation doctrine reflects a fundamental maxim of separation of powers. John Locke defined legislative power as a nontransferable "delegated power from the people" and a sovereign authority that permits the legislature "only to make laws, and not

\footnotetext{
${ }^{33}$ See infra Part III.

${ }^{34}$ See infra Sections III.A.4, III.B.2.
} 
to make legislators." ${ }^{55}$ Legislative delegations themselves reflect a rich background of legal traditions and political theories developed outside of the United States. ${ }^{36}$ Toward the end of the eighteenth century, however, even a Framer who had read every treatise on the shelf would still have many questions about delegation of legislative powers under the United States' new Constitution.

The problem of defining legislative power perplexed James Madison from the start. As a delegate to the Constitutional Convention, Madison brought "a strong bias in favor of an enumeration and definition of powers necessary to be exercised by the national Legislature." ${ }^{37}$ At the same time, Madison harbored "doubts concerning [the] practicability" of this undertaking. ${ }^{38}$ At one point, he even became "convinced" that a definition "of the limits and powers of the federal Legislature . . could not be done." 39

Early debates at the Constitutional Convention did not involve precise definitions. They nevertheless focused on concepts important to delegation, and Madison in particular worried about an unduly limited executive role. He moved for an amendment clarifying that the Executive has the power not only to "carry into effect[] the national laws" but also "to execute such other powers ... as may from time to time be delegated by the national Legislature." 40 Madison also agreed to specify in his amendment that these "other" delegated powers not be "improper" - that is, the powers must not be "Legislative [or] Judiciary in their nature." ${ }^{11}$ The delegates ultimately rejected Madison's amendment as "unnecessary" based on the understanding that its "object" (i.e.,

35 John Locke, The Second Treatise of Civil Government 100 (Andrew Bailey ed., 2015).

36 See, e.g., Mortenson \& Bagley, supra note 11, at 293-313 (discussing views held by the "most influential contemporary political theorists of the Framer's era" and delegation practice in England); Hamburger, supra note 10, at 96-101 (contesting assertions of "a monolithic European view on delegation”).

371 The Records of the Federal Convention of 178753 (Max Farrand ed., 1911) [hereinafter FARRAND's RECORDS].

${ }^{38} I d$.

${ }^{39} I d$. at 60.

${ }^{40} \mathrm{Id}$. at 67 ; see also Michael W. McConnell, The President Who Would Not Be KinG: Executive Power UNDER The Constitution 328-29 (2020) (noting that "other powers" to which Madison referred may have been prerogative Crown powers such as borrowing money).

${ }^{41}$ FARRAND's RECORDS, supra note 37 , at 67. 
delegation of "other powers") was already "included in the "power to carry into effect the national laws." 42 The delegates said nothing about removal of accompanying language that limited "improper" delegations of powers that were legislative or judicial in nature. ${ }^{43}$

The Constitution that emerged from the Convention left open many questions about the relationship between legislative and executive powers. In The Federalist, Madison recognized continued challenges of distinguishing legislative powers from other powers of government: "[N]o skill in the science of government has yet been able to discriminate and define, with sufficient certainty, its three great provinces - the legislative, executive, and judiciary ...."44 This difficulty did not eliminate the need to address separation of powers concerns, however, as Madison recognized objections that "[t]here can be no liberty where the legislative and executive powers are united in the same person." 45 For Madison, this separation of powers concern did not prevent the legislative and executive departments from possessing "partial agency in ... the acts of each other." 46 Separation of powers instead required that "the whole power of one department" not be "exercised by the same hands which possess the whole power of another department." ${ }^{47}$ According to Madison, the Constitution met this requirement: "The magistrate in whom the whole executive power resides cannot of himself make a law, though he can put a negative on every law . . ." ${ }^{48}$ In other words, Article I, Section 7 prevented the President from making law on his own.

This understanding of Section 7's lawmaking procedures left unresolved questions about Congress's ability to enlist the Executive Branch in carrying out sovereign powers vested in Congress. Article I, Section 1 vests "[a]ll legislative Powers herein

\footnotetext{
${ }^{42} I d$.

${ }^{43} I d$.

44 The Federalist No. 37, at 224 (James Madison) (Clinton Rossiter ed., 1961).

45 The Federalist No. 47, supra note 44, at 299 (James Madison) (quoting Montesquieu).

${ }^{46} I d$.

${ }^{47} I d$. Madison later expressed a similar concern that "a general conveyance of authority, without laying down any precise rules" might allow the "whole power of legislation" to be "transferred by the legislature from itself." JAMES MADISON, THE REPORT OF 1800 (1800), https://founders.archives.gov/documents/Madison/01-17-02-0202.

48 The Federalist No. 47, supra note 44, at 300 (James Madison).
} 
granted" in Congress, ${ }^{49}$ and Article I, Section 7 specifies bicameralism and presentment as procedures that Congress and the President must follow in order to enact a law. ${ }^{50}$ Article I, Section 8 enumerates the substantive, sovereign powers vested in Congress. These powers include the power to "lay and collect Taxes," to "borrow money on the Credit of the United States," and to "regulate Commerce with foreign Nations] and among the several States," among others. ${ }^{51}$ The final clause in Article I, Section 8 is the Sweeping Clause. ${ }^{52}$ This Clause anticipates law execution and directs Congress to "make . . . Laws" (that is, to take official action under Section 7) when it delegates Section 8 powers to the Executive Branch. ${ }^{53}$ The Sweeping Clause does not empower Congress to make "all Laws," period. Instead, it directs Congress to make "all Laws which shall be necessary and proper for carrying into Execution the foregoing Powers" enumerated at the beginning of Section $8 .^{54}$

At the very least, the text of Article I requires Congress itself to implement Article I, Section 7's procedures when passing laws. 55 Some scholars claim that voting on bills is one of the few nondelegable legislative powers under Article I and that delegation concerns never extend to the amount of discretionary power that a law gives to the Executive. ${ }^{56}$ But this understanding may not give adequate consideration to the sovereign powers vested in Congress pursuant to Article I, Section 8. Consider the following hypothetical statute: following procedures set forth in Article I, Section 7, Congress passes a statute that copies verbatim the "foregoing"

\footnotetext{
49 U.S. CoNsT. art. I, $\S 1$.

50 U.S. CONST. art. I, § 7.

${ }^{51}$ U.S. CONST. art. I, $\S 8$.

${ }^{52} I d$.

${ }^{53} I d$.

${ }^{54} I d$. The clause concludes, "and all other Powers vested by this Constitution in the Government of the United States, or in any Department or Officer thereof." Id.

55 See INS v. Chadha, 462 U.S. 919, 945-51 (1983) (holding that Congress cannot take binding action outside of Article I, Section 7 procedures).

56 Posner \& Vermeule, supra note 6, at 1723 (arguing that Congress has unlimited power to "grant . . . authority to the executive" so long as it does not "delegate to anyone else the authority to vote on federal statutes"); accord Mortenson \& Bagley, supra note 11, at 280 (same).
} 
legislative powers enumerated in Article I, Section 8. ${ }^{57}$ This statute may include all clauses of Section 8, from "Power To lay and collect Taxes" to power "To exercise exclusive Legislation" over the seat of government, or it may include all of a particular sovereign power such as the borrowing power or the power to establish post roads. ${ }^{58}$ In either case, the statute would hand off a Section 8 power or powers to the Executive Branch, wholesale.

Such a statute would delegate to the Executive the entirety of the sovereign power or powers that Section 8 vested in Congress, but without a constitutional amendment to formally alter Article I's original allocation of powers. This arrangement would seem to implicate Madison's concern about the "whole power of one department" being "exercised by the same hands which possess the whole power of another department." 59 Indeed, delegation of an entire Section 8 power might amount to an alienation or impermissible transfer of power in a way that delegation of part of this power would not. Although, in theory, Congress could always undo a delegation by passing another law, a legislature that has handed off the entirety of a particular power may not be able to do so. To undo any delegation, additional legislation would require either the President's approval or a supermajority of Congress. ${ }^{60} \mathrm{~A}$ President naturally may be less willing to cede power than she was to accept it in the first place. In a case where the President already possesses all Article I, Section 8 powers, then Congress may lack the bargaining chips it would need: discretion to withhold or grant additional powers in future legislation in order to convince the President to cede existing power. The same dynamic would also apply if the President possessed the whole of a particular power under Section 8. Finally, delegation of the entirety of certain Section 8 powers, such as borrowing, might allow the President to exhaust the United States' entire borrowing capacity for some time. As a practical matter, this would leave no immediate borrowing power for Congress to regain in subsequent legislation. These are all

\footnotetext{
${ }^{57}$ Cf. Posner \& Vermeule, supra note 6, at 1756 (discussing a hypothetical statute delegating Section 7 power to vote on bills).

58 U.S. CONST. art I, § 8.

59 The Federalist No. 47, supra note 44, at 299 (James Madison).

60 See Hamburger, supra note 10, at 109 (stating that Congress "cannot always recall" powers it transfers).
} 
reasons why a Congress that retains some portion of an Article I, Section 8 power may be different than one that retains none of that power.

The text of the Constitution does not address this concern directly, but it does require laws that delegate Article I, Section 8 authority to be "necessary and proper." ${ }^{1}$ Some originalists have argued that a law must respect the Constitution's structural commitments in order to be "proper." 62 The hypothetical statute described above would arguably upset Section 8's allocation of certain powers to Congress. While the hypothetical cession of Article I, Section 8 powers may seem extreme, this possibility resonates with concerns that members of early Congresses expressed in debates over delegation. Representative Page raised this exact point when debating delegation of power to establish post roads: "[I]f this House can, with propriety, leave the business of the post office to the President, it may leave to him any other business of legislation ...."63 If this were the case, continued Page, he proposed that Congress "adjourn and leave all the objects of legislation to [the President's] sole consideration and direction." 64 Page suggested that delegation of all legislative powers would be unconstitutional, ${ }^{65}$ and members of Congress expressed similar concerns about laws that would delegate great amounts of the legislative powers to borrow money and establish post roads under Article I, Section 8. ${ }^{66}$ Laws delegating these powers to the Executive would seem to contradict the Constitution's textual commitment of these powers to Congress.

The text of Article I does not provide a doctrinal test or specify how much of a particular power may be delegated without creating an "improper" transfer of legislative power. There is no ban on delegating an entire Section 8 power or "important subjects" related to such power. Nor is there a requirement that the delegation be

\footnotetext{
${ }^{61}$ U.S. CONST. art $1, \S 8$.

${ }^{62}$ See, e.g., Gary Lawson \& Patricia B. Granger, The "Proper" Scope of Federal Power: A Jurisdictional Interpretation of the Sweeping Clause, 43 DUKE L.J. 267, 334 (1993) (arguing that Congress "must respect" "proper' principles of governmental structure" and avoid "delegation of legislative power").

633 ANNALS OF CONG. 233-34 (1791) (statement of Rep. Page); Wurman, supra note 12, at 1507.

643 ANNAls of CONG. 233 (1791) (statement of Rep. Page).

65 Id. at $233-34$.

${ }^{66}$ See infra Section III (introduction) \& Section III.A.2.
} 
limited by an "intelligible principle." All of these potential limitations on Congress's power to delegate are contingent on the historical record and the limitations on delegation that were recognized in the Founding Era. As Professors Bagley and Mortenson aptly note, "nondelegation doctrine is not a logically required implication of the bare constitutional text. History is thus the linchpin of the originalist case." 67 The subsection below outlines key delegation doctrines developed by courts and describes the legal framework against which the historical record will be measured.

\section{B. PRECEDENT: IMPORTANT SUBJECTS AND INTELLIGIBLE PRINCIPLES}

Courts have also struggled to identify the constitutional boundaries of permissible delegation. On the rare occasions when the Supreme Court reviewed Congress's early delegations, the Court validated Congress's allocations of power to the Executive and Judicial Branches. ${ }^{68}$ In an important early decision in Wayman v. Southard, Chief Justice Marshall considered whether a federal statute unconstitutionally delegated legislative power when it authorized federal courts to make certain "alterations and additions" to procedures for execution of judgment. ${ }^{69}$ Chief Justice Marshall explained that Congress cannot delegate "powers which are strictly and exclusively legislative."70 In other cases, however, legislative powers overlap with powers of other branches, and "Congress may certainly delegate to others[] powers which the legislature may rightfully exercise itself."71 Echoing James Madison, the Court noted the lack of a clear test to distinguish "exclusively legislative" powers from powers that Congress could delegate to other branches: "The line has not been exactly drawn which separates those important subjects, which must be entirely

\footnotetext{
${ }^{67}$ Mortenson \& Bagley, supra note 11, at 291.

68 See, e.g., Cargo of the Brig Aurora v. United States, 11 U.S. (7 Cranch) 382, 388 (1813) (rejecting summarily a constitutional challenge to Congress's delegation of "discretion" to revive certain trade restrictions).

69 Wayman v. Southard, 23 U.S. (10 Wheat.) 1, 41 (1825) (quoting Process Act of 1792, ch. $36, \S 2$, 1 Stat. 275,276$)$.

${ }^{70} \mathrm{Id}$. at $42-43$.

71 Id. at 43 .
} 
regulated by the legislature itself, from those of less interest, in which a general provision may be made" for officers "to fill up the details."72 The Court declined to draw this line in Wayman. ${ }^{73}$ It left the question of exactly which "important subjects" must be specified "within the great outlines marked out by the legislature" unanswered..$^{74}$

The Supreme Court's early validations of federal legislation began a virtually unbroken string of cases in which the Supreme Court validated delegations in other statutes. In J.W. Hampton, Jr., \& Co. v. United States, Chief Justice Taft articulated an important doctrinal test to distinguish impermissible delegations of exclusively legislative powers from permissible delegations of overlapping powers. ${ }^{75}$ His test drew a line between permissible delegations in which Congress established an "intelligible principle" to guide execution of the law and impermissible delegations in which the Executive operated without the benefit of such guidance. ${ }^{76}$ Writing for the Court, Taft held that the Tariff Act of 1922 did not afford "a forbidden delegation of legislative power" to lay and collect taxes because Congress had established "an intelligible principle" to which the President (then Calvin Coolidge) was "directed to conform" when increasing certain tariffs on imported goods. ${ }^{77}$

Chief Justice Taft was no stranger to Founding-era history, and his application of the intelligible principle test did not require Congress to resolve all important policy questions. The Tariff Act created a general "policy and plan" for tariffs to equalize differences between the costs of producing goods in foreign countries and the United States. ${ }^{78}$ But when Congress delegated its power to "lay and

\footnotetext{
${ }^{72} I d$. at $42-43$ (emphasis added).

${ }^{73}$ See id. at 46 (explaining that "the precise boundary" of power that may be committed "to the discretion of the other departments" is a "delicate and difficult inquiry, into which a Court will not enter unnecessarily"); id. at 48-49 (noting that the certified question before the Court omitted "the question respecting the right of the Courts to alter" procedures under the Process Act).

${ }^{74} \mathrm{Id}$. at 43,45 .

75276 U.S. 394, 409 (1928).

${ }^{76} \mathrm{Id}$.

${ }^{77} \mathrm{Id}$.

${ }^{78} \mathrm{Id}$. at 405 .
} 
collect Taxes" under Article I, Section 8, ${ }^{79}$ Congress handed off the critical and dynamic questions of determining differences in costs and equalizing increases in tariffs to the President. ${ }^{80}$ Statutory provisions for determination of differences in cost were not so formulaic as to obviate policy decisions, ${ }^{81}$ and the function of determining these cost differences was such "a matter of great importance" that Congress delegated it "by statute to the President" himself. ${ }^{82}$ The Chief Justice also considered Congress's structural disadvantage in resolving dynamic questions and acknowledged the necessity of delegation that reflected "common sense and the inherent necessities" of "governmental co-ordination." ${ }^{33}$

In subsequent cases, the Court did not require Congress to resolve all important policy questions and applied the intelligible principle doctrine to validate broadly worded federal legislation. The nondelegation doctrine had one consequential year in 1935, when the Court held that two pieces of New Deal legislation failed to provide an intelligible principle to guide executive discretion. ${ }^{84}$ The Court has never since invalidated federal legislation on the ground that it unconstitutionally delegated legislative power to the Executive Branch.

After many cases in which the intelligible principle requirement failed to provide meaningful constraints, ${ }^{85}$ however, some jurists

\footnotetext{
79 U.S. CONST. art I, § 8.

${ }^{80}$ Hampton, 276 U.S. at 405.

81 The President had discretion to take into account "any other advantages or disadvantages in competition" beyond specified costs of production such as wages and cost of materials. Id. at 401-02 (quoting Tariff Act of 1922, ch. 356, § 315(c), 42 Stat. 858, 943, repealed by Tariff Act of 1930, ch. 497, § 651(a)(1), 46 Stat. 590, 762).

$82 I d$. at 405.

83 Id. at $405-06$.

${ }^{84}$ See Pan. Refin. Co. v. Ryan, 293 U.S. 388, 430 (1935) (“Congress has declared no policy, has established no standard, has laid down no rule.”); A.L.A. Schechter Poultry Corp. v. United States, 295 U.S. 495, 542 (1935) (holding that the President's "virtually unfettered" power to establish codes of fair competition amounted to "an unconstitutional delegation of legislative power"); see also Sunstein, supra note 6, at 322 (noting these cases); Carter v. Carter Coal Co., 298 U.S. 238, 310-11 (1936) (holding that a statute delegating "the power to fix maximum hours of labor to a part of the" private "producers and ... miners" amounted to "legislative delegation in its most obnoxious form" and was unconstitutional under Schechter).

${ }^{85}$ See, e.g., Yakus v. United States, 321 U.S. 414, 427 (1944) (approving a delegation of power to fix "fair and equitable" prices under the Emergency Price Control Act).
} 
began to question the breadth of delegation permitted by governing doctrine. In Industrial Union Department, AFL-CIO v. American Petroleum Institute (the Benzene case), the Court reviewed a health standard that was promulgated under the Occupational Safety and Health Act and severely limited employees' exposure to the toxic chemical benzene. ${ }^{86}$ The Act arguably afforded sweeping power to eliminate health risks based on exposure to toxic materials, and the Justices addressed whether the law amounted to an unconstitutional delegation of legislative power to the Secretary of Labor. ${ }^{87}$ Then-Justice Rehnquist concurred in the decision to remand the issue to the Secretary of Labor. ${ }^{88} \mathrm{He}$ argued that the Act's requirement that exposure be safe "to the extent feasible" amounted to an "uncanalized delegation[] of legislative power" and that the Secretary should be limited to "setting a safe standard or setting no standard at all" on remand. ${ }^{89}$ According to Justice Rehnquist, Congress failed to decide "whether the statistical possibility of future deaths should ever be disregarded in light of the economic costs,"90 and the feasibility loophole in the Act gave the Secretary "absolutely no indication where on the continuum of relative safety he should draw his line." ${ }^{1}$

Justice Rehnquist concluded that the Act failed to supply an intelligible principle to guide the Secretary's regulation and did not overtly challenge this doctrinal requirement. ${ }^{92}$ At the same time, Justice Rehnquist echoed Chief Justice Marshall's concerns in Wayman when he focused on the "character" of the question Congress failed to decide. ${ }^{93}$ Justice Rehnquist noted that the question of "whether the law of diminishing returns should have

\footnotetext{
86 Indus. Union Dep’t v. Am. Petroleum Inst. (Benzene), 448 U.S. 607, 611 (1980) (plurality opinion).

87 Justice Stevens's plurality opinion interpreted the Act to require a finding of "significant risk" and affirmed the Fifth Circuit's decision to remand the matter to the Secretary for further proceedings consistent with this interpretation. $I d$. at $646,662$.

${ }^{88} \mathrm{Id}$. at $671-88$ (Rehnquist, J., concurring).

${ }^{89} \mathrm{Id}$. at $675,681,688$.

${ }^{90} I d$. at 672 .

91 Id. at 675 .

${ }^{92} I d$. at $685-86$.

${ }^{93}$ Id. at 674 (quoting J.W. Hampton, Jr., \& Co., v. United States, 276 U.S. 394, 406 (1928)); see also Wayman v. Southard, 23 U.S. (10 Wheat.) 1, 43 (1825) (considering "the character of the power given to the Courts by the Process Act").
} 
any place in the regulation of toxic substances [was] quintessentially one of legislative policy." 94 His analysis also emphasized Congress's obligation to resolve important policy questions and make "hard choices": "When fundamental policy decisions underlying important legislation about to be enacted are to be made, the buck stops with Congress . . .."95

Justice Rehnquist's argument did not turn on importance alone. He grounded his analysis in a long line of decisions in which courts had approved statutes that merely laid "down the general policy and standards that animate the law."96 According to Rehnquist, these approvals depended "largely on the theory" that delegation was required because the field in which Congress chose to legislate was "sufficiently technical," covered too much ground, and exceeded Congress's limited expertise. ${ }^{97}$ To his mind, these decisions reflected Chief Justice Taft's understanding that "delegations of legislative authority must be judged 'according to common sense and the inherent necessities of the governmental co-ordination." 98 Rehnquist determined that it was not necessary for Congress to delegate an important question in the Occupational Safety and Health Act when the legislative history established that Congress had "simply avoid[ed] a choice" that it was "best suited" to make. ${ }^{99}$ In other words, because there was "no need for such an evasive standard as 'feasibility," the Act's broad delegation fell outside the "rule of necessity" that might permit generous delegations in other cases. ${ }^{100}$

\section{THE MANY FACES OF NONDELEGATION ORIGINALISM}

One might have expected Justice Rehnquist's concurrence in Benzene to set the stage for originalists to raise separation of powers

\footnotetext{
${ }^{94}$ Benzene, 448 U.S. at 686 (Rehnquist, J., concurring).

$95 \mathrm{Id}$. at 687.

${ }^{96} I d$. at 675 . Setting a "general policy" to "animate the law" is less demanding than Justice Gorsuch's requirement that Congress "make the policy judgments" and "assign to the executive only the responsibility to make factual findings." Compare id., with Gundy v. United States, 139 S. Ct. 2116, 2141 (2019) (Gorsuch, J., dissenting).

${ }^{97}$ Benzene, 448 U.S. at 675 (Rehnquist, J., concurring).

98 Id. at 674 (emphasis added) (quoting Hampton, 276 U.S. at 406).

${ }^{99} \mathrm{Id}$. at 672,687 .

${ }^{100} I d$. at $684-85$.
} 
arguments in support of a more assertive nondelegation doctrine. After INS v. Chadha, ${ }^{101}$ a 1983 decision in which the Supreme Court "struck down the one-house legislative veto on separation of powers grounds, litigators in the [Reagan] Justice Department" proffered originalist arguments to support "similar separation of powers challenges" in other cases before the Court. ${ }^{102}$ At the time, these originalist arguments had limited success. In Morrison v. Olson, for example, only Justice Scalia endorsed arguments that the original meaning of Article II established a unitary executive with "exclusive control over the exercise" of "executive power" by subordinate officers. ${ }^{103}$

Originalist arguments for an enhanced nondelegation doctrine failed to surface in leading Supreme Court opinions in the 1980s. Justice Scalia, for one, did not advocate a new nondelegation test (for most cases) in his dissent in Mistretta $v$. United States. ${ }^{104}$ Instead, he opined that the "doctrine of unconstitutional delegation . . . is not an element readily enforceable by the courts," as courts "have almost never felt qualified to second-guess Congress regarding the permissible degree of policy judgment that can be left to those executing or applying the law."105

Justice Scalia also stuck with precedent and the intelligible principle requirement in his 2001 decision in Whitman $v$. American Trucking Associations. ${ }^{106}$ When writing the majority opinion, he held that the Clean Air Act provisions authorizing the EPA to

\footnotetext{
101462 U.S. 919 (1983).
}

102 Amanda Hollis-Brusky, Helping Ideas Have Consequences: Political and Intellectual Investment in the Unitary Executive Theory, 1981-2000, 89 DENV. U. L. REV. 197, 206-09 (2011) (footnote omitted) (noting originalist arguments for a unitary executive in Bowsher $v$. Synar, 478 U.S. 714 (1986), and Morrison v. Olson, 487 U.S. 654 (1988)).

103487 U.S. at 705 (Scalia, J., dissenting); see Steven G. Calabresi \& Kevin H. Rhodes, The Structural Constitution: Unitary Executive, Plural Judiciary, 105 HARV. L. REV. 1153, 120102 (1992) (noting "Justice[] Scalia['s] theory of an absolute presidential power to remove at will principal subordinate officers"); see also Chabot, supra note 14, at 17-19 (discussing unitary executive arguments raised in the 1980s).

104488 U.S. 361, 413-27 (1989) (Scalia, J., dissenting).

${ }^{105}$ Id. at 415-16; see also Antonin Scalia, A Note on the Benzene Case, REgul., July-Aug. 1980, at 25, 26-27 (discussing the Benzene decision); William K. Kelley, Justice Scalia, the Nondelegation Doctrine, and Constitutional Argument, 92 Notre Dame L. REV. 2107, 2119 (2017) (noting that the "original meaning of the nondelegation doctrine" is "conspicuously absent in Justice Scalia's nondelegation jurisprudence").

106531 U.S. 457, 472 (2001). 
promulgate air quality rules "'requisite' . . . to protect the public health" passed constitutional muster. ${ }^{107}$ The EPA's broad rulemaking authority did not amount to an unconstitutional delegation of legislative power to the Executive Branch. ${ }^{108}$ For Justice Scalia, the presence of an intelligible principle (and not the agency's apparent lawmaking function) demarcated whether Congress unconstitutionally "delegated legislative power to the agency." 109 The intelligible principle requirement operated largely as a rule of deference to Congress. It also avoided the discretionary line drawing required by an important questions test, which seemed important to Justice Scalia. ${ }^{110}$ As Gary Lawson put it, it is "no surprise that a rule-of-law devotee like Justice Scalia" fled from the important questions test "as a vampire flees garlic." "111

Notwithstanding Justice Scalia's initial willingness to accommodate lax nondelegation standards, in more recent decades originalists have begun to dispute the intelligible principle requirement in earnest. In an apparent response to perceived excesses of executive or bureaucratic power, conservative jurists have railed against unchecked executive power with arguments ranging from attacks on Cheuron deference ${ }^{112}$ to calls for a reinvigorated originalist understanding of the nondelegation doctrine. ${ }^{113}$ At the same time, the Roberts Court has embraced originalist arguments supporting the strong unitary executive theory from Justice Scalia's 1988 dissent in Morrison. ${ }^{114}$ Perhaps

${ }^{107} I d$. at $475-76$.

${ }_{108} I d$.

${ }^{109} I d$. at 472 .

${ }_{110}$ See Kelley, supra note 105, at 2118 ("Justice Scalia's approach to the nondelegation doctrine fit naturally within his general aversion to arguments from degree.”).

${ }^{111}$ Lawson, supra note 5, at 361.

${ }^{112}$ In a dissenting opinion joined by Justice Thomas, Justice Gorsuch approved of "mounting criticism of Chevron deference." BNSF Ry. Co. v. Loos, 139 S. Ct. 893, 908 (2019) (Gorsuch, J., dissenting). Gorsuch criticized Chevron for allowing the "federal government's executive branch" to "dictate an inferior interpretation of the law that may be more the product of politics than a scrupulous reading of the statute." Id. at 908-09.

${ }^{113}$ See supra notes 10, 12 (listing originalist works supporting a stronger nondelegation doctrine).

114 See, e.g., Seila L. LLC v. Consumer Fin. Prot. Bureau, 140 S. Ct. 2183, 2191 (2020) ("Under our Constitution, the 'executive Power'-all of it—is 'vested in a President' . ..." (quoting U.S. ConsT. art. II, § 1, cl. 1)); Free Enter. Fund v. Pub. Co. Acct. Oversight Bd., 561 
ironically, these originalist arguments skew in favor of the Executive Branch: they rest on a selective historical record ${ }^{115}$ and fail to account for recent scholarship bringing to light structural limitations that Alexander Hamilton, the First Congress, and George Washington adopted to constrain executive power in the Founding Era. ${ }^{116}$ The Founding Era's structural checks on executive removal power offer a generally overlooked originalist alternative to the substantive checks that proponents of a stronger nondelegation doctrine call for today. But instead of considering this alternative for reining in executive power, conventional originalist arguments have focused on a stronger nondelegation doctrine. ${ }^{117}$

The originalist shift to calls for a stronger nondelegation doctrine surfaced in judicial opinions written by Justice Thomas in Whitman v. American Trucking ${ }^{118}$ and then in Department of Transportation v. Association of American Railroads. ${ }^{119}$ Now, in the

U.S. 477, 483 (2010) ("Since 1789, the Constitution has been understood to empower the President to keep ... officers accountable-by removing them from office, if necessary.”).

115 Ganesh Sitaraman, The Political Economy of the Removal Power, 134 HARV. L. REV. 352, 386-87 (2020) ("[Justices may] cherry-pick[ evidence that supports a predetermined policy position.").

116 Contrary to originalist orthodoxy, Alexander Hamilton, the First Congress, and George Washington all agreed to check executive power through statutory provisions that limited the President's removal power and dispersed key decisions amongst multiple actors. See Chabot, supra note 14, at 37-43 (explaining how the First Congress established an "independent," "multimember" Sinking Fund Commission to check unlawful disbursements of funds by the President); Christine Kexel Chabot, Interring the Unitary Executive 3 (Sept. 10, 2021) (unpublished manuscript), https://papers.ssrn.com/sol3/papers.cfm?abstract_id=3921776 (recounting how the First Congress passed dozens of independent regulatory structures in order to check unlawful executive action); see also Jed Handelsman Shugerman, Presidential Removal: The Marbury Problem and the Madison Solutions, 89 FoRDHAM L. REV. 2085, 2088 (2021) (summarizing recent research supporting the conclusion that Article II "did not 'vest' exclusive removal power" in the President).

117 Justice Gorsuch, for example, rejected structural limits on removal as an "encroachment on the power of the Executive" when he joined Justice Thomas's opinion in Seila Law, 140 S. Ct. at 2212 (Thomas, J., concurring), while he urged a stronger nondelegation doctrine to check the "proliferation of new executive programs" established by Congress in Gundy $v$. United States, 139 S. Ct. 2116, 2137 (2019) (Gorsuch, J., dissenting).

118 See 531 U.S. 457, 487 (2001) (Thomas, J., concurring) (inviting the Court to revisit nondelegation "[o]n a future day" when "the significance of the delegated decision is simply too great for the decision to be called anything other than "legislative").

119 See 575 U.S. 43, 76 (2015) (Thomas, J., concurring) ("[T]he core of the legislative power that the Framers sought to protect from consolidation with the executive . . . [involves] generally applicable rules of private conduct."). 
wake of Gundy, it is doubtful that the intelligible principle requirement will continue to draw a majority of the Court. Although five Justices validated the Sex Offender Registration and Notification Act under the intelligible principle requirement in Gundy, ${ }^{120}$ two of these votes are up for grabs. Justice Ginsburg is no longer on the Court and has been replaced by Justice Barrett. Further, Justice Alito indicated that he would switch his vote if the Court gained votes to overturn the intelligible principle requirement in the future. ${ }^{121}$ Justice Kavanaugh did not participate in Gundy but later signaled a likely fifth vote for a stronger doctrine in Paul v. United States. ${ }^{122}$ He urged a "nondelegation principle for major questions," based on the understanding that important or "major national policy decisions must be made by Congress and the President in the legislative process." 123 These opinions suggest that Justice Gorsuch will have the votes he needs to eliminate the intelligible principle requirement in a future case.

It's less clear what the new test would be. Parts of Justice Gorsuch's dissent in Gundy embraced a broad, formalist view of non-delegable legislative powers. According to Gorsuch, Congress must "announce[] the controlling general policy," set forth "sufficiently definite and precise" standards by which courts and others may ascertain compliance, and "prescribe] the rule governing private conduct." ${ }^{24}$ The Executive's role would then be limited to "fact-finding," except in cases where the statute involves "foreign affairs" or other powers "constitutionally vested in the

\footnotetext{
120 Justice Kagan's opinion, which was joined by Justices Ginsburg, Breyer, and Sotomayor, found that the Act contained an intelligible principle because it required, by implication, that the Attorney General apply the Act's "registration requirements as soon as feasible to offenders convicted before the statute's enactment." Gundy, 139 S. Ct. at 2121 (plurality opinion). Justice Alito wrote separately to concur in the judgment, and Justice Kavanaugh took no part in the case. Id. at 2130. Only Chief Justice Roberts and Justice Thomas joined Justice Gorsuch in dissent. Id. at 2131 (Gorsuch, J., dissenting).

${ }^{121} \mathrm{See} i d$. at 2131 (Alito, J., concurring) ("If a majority of this Court were willing to reconsider the approach we have taken for the past 84 years, I would support that effort.").

122 See 140 S. Ct. 342, 342 (2019) (statement of Kavanaugh, J. respecting the denial of certiorari) (“Justice Gorsuch's scholarly analysis of the Constitution's nondelegation doctrine in his Gundy dissent may warrant further consideration in future cases.”).

${ }^{123} I d$.

${ }^{124}$ Gundy, 139 S. Ct. at 2136 (Gorsuch, J., dissenting) (quoting Yakus v. United States, 321 U.S. 414, 426 (1944)); id. at 2143.
} 
president under Article II.”125 Other elements of Justice Gorsuch's analysis seemed amenable to the important questions requirement urged by Justice Kavanaugh. Justice Gorsuch cited Justice Rehnquist's concurrence in the Benzene case, ${ }^{126}$ and Justice Gorsuch recognized the Executive's power to "fill up the details." 127 Nor did Gorsuch need to choose between the two tests in Gundy. As he explained, the Act granted the Attorney General broad discretion to determine whether its registration requirements and criminal penalties would apply to pre-Act sex offenders. ${ }^{128}$ Justice Gorsuch found that this delegation impermissibly granted power to establish new requirements of criminal law and thus "make the important policy choices' that belong to Congress." 129

Justice Gorsuch is no faint-hearted originalist, and in Gundy he unabashedly urged the Court to set aside "an understanding of the Constitution" that he believed to be "at war with its text and history." 130 According to him, "federal statutes granting authority to the executive were comparatively modest" "[b]efore the 1930s,"131 and only more recently has the Court's lax application of the intelligible principle requirement failed to constrain impermissible delegations of legislative powers. ${ }^{132}$ Gorsuch's historical assumptions led him to conclude that the current intelligible principle requirement "has no basis in the original meaning of the Constitution" or "in history." 133

As noted above, Justice Gorsuch's analysis relied on deficient accounts of Founding-era history, ${ }^{134}$ and his dissent has inspired invaluable new scholarship in which researchers have turned a

${ }^{125} \mathrm{Id}$. at $2136-37$.

${ }^{126} I d$. at 2145 (citing Indus. Union Dep't v. Am. Petroleum Inst. (Benzene), 448 U.S. 607, 676, 685-86 (1980) (Rehnquist, J., concurring)); see also Paul, 140 S. Ct. at 342 (statement of Kavanaugh, J. respecting the denial of certiorari) (noting that Justice Gorsuch's "opinion built on views expressed by then-Justice Rehnquist some 40 years ago in" the Benzene case).

${ }^{127}$ Gundy, 139 S. Ct. at 2136 (Gorsuch, J., dissenting).

${ }^{128}$ Id. at 2131-32.

${ }^{129} I d$. at 2145 (quoting Benzene, 448 U.S. at 676 (Rehnquist, J., concurring)).

${ }^{130} \mathrm{Id}$. at 2131.

$131 \mathrm{Id}$. at 2137.

${ }^{132} I d$. at 2138 (noting that "the Court hasn't held another statute to violate the separation of powers in the same way" since the New Deal).

133 Id. at 2139.

${ }^{134}$ See supra note 5. 
more careful eye back to the Founding Era. ${ }^{135}$ This scholarship plays a critical role in testing Justice Gorsuch's historical assumptions and determining the fate of originalist arguments for a more muscular nondelegation doctrine. Founding-era history is essential to originalists of all stripes, ${ }^{136}$ especially for a nondelegation doctrine that rests on the vague textual contours of "legislative powers," "necessary and proper" laws, and the "executive power."137 As the Supreme Court has reiterated, "the practice of the First Congress is strong evidence of the original meaning of the Constitution."138 Recent research has also focused on early congressional debates over delegation of power to establish post roads ${ }^{139}$ and delegations in legislation that imposed the first direct taxes under the new Constitution. ${ }^{140}$

The historical record does not support the broader formalist conceptions of nondelegable legislative powers urged by Justice Gorsuch in Gundy. Michael Rappaport outlines formalist claims that nondelegation concerns categorically barred delegation involving "coercion of private rights in the domestic sphere," while placing no limits on delegation that implicated public rights. ${ }^{141}$ This

\footnotetext{
135 See supra notes 10-12.

${ }^{136}$ See Chabot, supra note 14, at 20-21 (noting the import of historical evidence for all "families" of originalism).

${ }_{137}$ See Lawrence B. Solum, The Fixation Thesis: The Role of Historical Fact in Original Meaning, 91 NoTRE DAME L. REV. 1, 11 (2015) (describing "legislative power" and "executive power" as "vague" phrases that admit of "borderline cases").

138 Fin. Oversight \& Mgmt. Bd. for P.R. v. Aurelius Inv., LLC, 140 S. Ct. 1649, 1659 (2020); see also Bowsher v. Synar, 478 U.S. 714, 723-24 (1986) (finding that an act passed by the First Congress assembled under the Constitution, many of whose members "had taken part in framing that instrument," offers "contemporaneous and weighty evidence' of the Constitution's meaning” (quoting Marsh v. Chambers, 463 U.S. 783, 790 (1983))); J.W. Hampton, Jr., \& Co. v. United States, 276 U.S. 394, 412 (1928) (emphasizing the importance of the First Congress's "contemporaneous legislative exposition of the Constitution when the founders of our government and framers of our Constitution were actively participating in public affairs" (citing Myers v. United States, 272 U.S. 52 (1926))).

139 Wurman, supra note 12, at 1506-12 (discussing "the post-roads debate"); Mortenson \& Bagley, supra note 11, at 350 (discussing "the Second Congress's debate over the nation's post roads").

${ }^{140}$ See generally, e.g., Parrillo, supra note 10 (discussing the Executive's rulemaking power under the "direct tax" of 1798).

141 See Rappaport, supra note 10, at 3, 7 ("While the strict tier applies to the regulation of private rights, the lenient tier extends to public rights."); MCCONNELL, supra note 40, at 32829 (borrowing is a delegable "prerogative power" that involves "the management or control of
} 
two-tiered doctrine is difficult to reconcile with the text of Article I, which defines "legislative powers" to include sovereign powers affecting both public and private rights. ${ }^{142}$ Nor does it align with early congressional debates over the delegation of legislative powers, as these debates focused on the constitutionality of delegating important public determinations regarding borrowing and post roads. ${ }^{143}$ Supporters of the two-tiered doctrine instead rely on implicit background understandings from eighteenth-century England ${ }^{144}$ and a "negative inference" drawn from an understanding that early Congresses delegated broadly with respect to public but not private rights. ${ }^{145}$

None of these arguments anticipated Nick Parrillo's groundbreaking research on the first direct taxes imposed under the new Constitution. ${ }^{146}$ Parrillo explains that proponents of the twotiered doctrine have missed the direct tax legislation as a "major counterexample" of Founding-era delegations that involved "coercive and domestic" regulation of private rights. ${ }^{147}$ The direct tax legislation operated largely as "a tax on real estate" 148 and established "a federal board of tax commissioners" for each state. ${ }^{149}$ These multi-member boards consisted of principal executive

\footnotetext{
various government resources or activities rather than lawmaking"); id. at 100 (arguing that the "power to tax" was an "exclusively legislative" power); Mascott, supra note 10, at 1449 ("[M]embers of Congress viewed themselves as the actors responsible for reaching finely grained policy determinations ... [to] bind the public.”); cf. Hamburger, supra note 10, at 107 ("[E]xecutive power is the nation's force and does not include the power to create rules or adjudications with legal obligation.”).

142 U.S. CONST. art. I, § 8.

${ }^{143}$ See infra Section III.A.2 \& Part IV.

144 See MCCONNELL, supra note 40, at 331 (arguing that the distinction between delegable "prerogative powers" and the non-delegable "legislative power to make laws binding on the people" "corresponds ... to the line drawn by the King's Bench in The Case of Proclamations and restated by Blackstone").

${ }^{145}$ Parrillo, supra note 10, at 1302 n.49 ("In general, a negative inference can be drawn . . . if early Congresses refrained from doing the action." (emphasis added) (citing Alden v. Maine, 527 U.S. 706, 743-44 (1999))); see also Hamburger, supra note 10, at 107 (asserting the lack of evidence that the Executive imposed "binding rules or adjudications" in the United States).

146 See generally Parrillo, supra note 10 (providing "the first in-depth study of the administration of the 1798 direct tax").

${ }^{147} I d$. at 1302 .

$148 \mathrm{Id}$. at 1326.

${ }^{149} \mathrm{Id}$. at 1327 .
} 
officers ${ }^{150}$ who were tasked with determining "just and equitable" valuations for particular tax assessment districts in each state. ${ }^{151}$ The legislation granted officers great discretion under an "openended" allowance for "just and equitable" valuations ${ }^{152}$ and forced them to make controversial policy choices when adjusting tax burdens. ${ }^{153}$ The delegation of binding rulemaking power to these officers drew no constitutional objections and ultimately became a settled practice in the United States. ${ }^{154}$ Parrillo's research casts grave doubt on claims that a two-tiered doctrine became part of our Constitution.

This research leaves open a substantial debate about the continued viability of Justice Gorsuch's originalist arguments for a stronger nondelegation doctrine. In a leading article, Nicholas Bagley and Julian Davis Mortenson contend that "[t]here was no nondelegation doctrine at the Founding." 155 They base this assertion on extensive analysis of pre-ratification materials, ${ }^{156}$ as well as an overview of Founding-era legislation in which Congress delegated broadly and without constitutional objections. ${ }^{157}$ While the constitutionality of some of these delegations may depend on whether they implicate powers that Article II assigns to the Executive, ${ }^{158}$ Bagley and Mortenson offer examples that do not present this concern. In the first Patent Act, for example, Congress

${ }^{150} \mathrm{Id}$. at $1327-28$.

${ }^{151} I d$. at 1339 (quoting Valuation \& Enumeration Act, ch. 70, § 22, 1 Stat. 580, 589 (1798)).

$152 I d$. at 1369 .

${ }^{153}$ See id. at 1393-94 (anticipating disputes over relative tax burdens for urban and rural areas); see also id. at 1403 (disputing applicability of state valuation laws).

${ }_{154}$ See id. at 1430-31 (noting "absence of recorded constitutional objections" to this practice); see also id. at 1429-37 (describing the "enduring acceptance" of rulemaking power in later direct tax legislation).

155 Mortenson \& Bagley, supra note 11, at 367.

156 See id. at 289-332.

157 See id. at 332-49 (examining various areas in which the First Congress delegated its authority).

158 Compare Gundy v. United States, 139 S. Ct. 2116, 2137 (2019) (Gorsuch, J., dissenting) (recognizing a greater allowance for delegation of "powers . . . constitutionally vested in the president under Article II"), with Mortenson \& Bagley, supra note 11, at 280 (advocating for an "empty vessel" theory of executive power that would likely not provide the allowance recognized by Gorsuch), and Wurman, supra note 12, at 1544 (arguing that some of the generous delegations described by Mortenson and Bagley fall "within the 'constitutional space' of another branch"). 
delegated its Article I, Section 8 power to grant exclusive patent rights to a Patent Board.159 This statute left many important questions unanswered, and Bagley and Mortenson recount how it required the Board to establish rules requiring that inventions be nonobvious. ${ }^{160}$ In patent law, the doctrine of nonobviousness is an important requirement that forces inventors to show a higher level of creativity than novelty alone, and John Duffy describes this doctrine as a "central and fundamental pillar of innovation law."161

Based on their survey of early statutes and other historical materials, Bagley and Mortenson conclude that the "Constitution at the Founding contained no discernable . . . prohibition on delegations of legislative power, . . . so long as the exercise of that power remained subject to congressional oversight." 162 While their primary targets are originalist arguments for a stronger nondelegation doctrine, Bagley and Mortenson's refusal to recognize any substantive limits on delegation carries broader implications. On their view, as an originalist matter, courts could never strike down legislation for lack of an intelligible principle. ${ }^{163}$ But their overview of early statutory provisions omits significant contextual evidence, including the First Congress's debates over the constitutionality of delegating borrowing power as well as policies that executive officers ended up determining pursuant to debt and patent legislation. ${ }^{164}$

In a leading response, Ilan Wurman attempts to trace the important questions distinction from Wayman back to the

\footnotetext{
159 See Act of Apr. 10, 1790, ch. 7, 1 Stat. 109.

160 See Mortenson \& Bagley, supra note 11, at 338-39. These rules most likely reflected guiding principles articulated in individualized rulings issued by the Patent Board.

161 John F. Duffy, Inventing Invention: A Case Study of Legal Innovation, 86 TEX. L. REV. $1,2,6$ (2007).

162 Mortenson \& Bagley, supra note 11, at 280.

${ }^{163} I d$. at 279-80. This approach aligns with the "naïve view" that "a statutory grant of authority to the executive branch . . . can never amount to a delegation of legislative power." Posner \& Vermeule, supra note 6, at 1723.

${ }^{164}$ Compare Mortenson \& Bagley, supra note 11, at 338-39, 344-45 (devoting just over one page to patent legislation and under two pages to debt legislation), with infra Part III (discussing the First Congress's debate over the delegation of borrowing power, important debt policies decided by the President and the Sinking Fund Commission, and the Patent Board's determination of legal parameters needed to resolve competing patent applications).
} 
Founding. ${ }^{165}$ Wurman identifies several episodes in which James Madison raised concerns over delegations of important legislative powers. ${ }^{166}$ While Madison's concerns were not always reduced to law and, in one instance, presented distinct constitutional concerns, ${ }^{167}$ Wurman recounts a critical episode in which James Madison and other members of the Second Congress disputed the constitutionality of a statutory amendment that would have delegated the power to establish post roads (another important Article I, Section 8 power) to the President. ${ }^{168}$ After this debate, Madison and other members of the Second Congress refused to delegate initial decisions on the placement of post roads to the Executive Branch. ${ }^{169}$ Based on his review of this episode and other Founding-era statutes and historical sources, Wurman concludes that "the picture the Founding-era history paints is one of a nondelegation doctrine whereby Congress could not delegate to the Executive decisions over "important subjects." 170 While he contends that originalism still justifies the move to a stronger nondelegation doctrine, his portrait concludes that delegations allowing regulation of "[p]rivate rights . . . are undoubtedly more important than" delegations involving "public" matters. ${ }^{171}$

\footnotetext{
165 See Wurman, supra note 12, at 1517 ("Marshall seems to have recognized that there is a category of 'exclusively' legislative power . . . that Congress could not delegate . ...”). Gary Lawson argues that the important questions distinction from Wayman can be explained by reference to the "private law of agency" in the eighteenth century. Lawson, supra note 12, at 20. The problem with Lawson's approach is that agency law created an inference of authority to subdelegate "at both tails of the distribution," or to resolve both the most and the least important questions at issue. Id. Thus, agency law actually permitted delegation of important questions.

166 See Wurman, supra note 12, at 1508, 1512 (noting Madison's objections to post roads legislation and the Alien Friends Act).

167 See id. at 1512-14 (describing Madison's opposition to the Alien Friends Act); see also $i d$. at 1515-16 (noting other nondelegation objections to bills that passed). The delegations effectuated by the Alien Friends Act created a "union of Legislative, Executive, and Judicial powers" in the President. Id. at 1514 (quoting 8 ANNALS OF ConG. 2008 (1798)). See generally CARol Berkin, A Sovereign People 201-10 (2017) (recounting debate over the Alien and Sedition Acts). Individualized applications of criminal and deportation laws by a lawmakerexecutioner-and-judge-in-one presented due process concerns distinct from those raised by other delegations of power to the Executive.

168 See Wurman, supra note 12 , at 1506-10.

$169 \mathrm{Id}$. at 1506.

170 Wurman, supra note 12 , at 1497.

${ }^{171} \mathrm{Id}$. at 1556.
} 
This Article moves the debate forward by supplying new originalist evidence of the restrained nondelegation doctrine that the First Congress applied to debt and intellectual property rightspublic matters that figures such as Hamilton, Madison, and Jefferson regarded as some of the most important questions facing our fledgling Republic. ${ }^{172}$ This evidence demonstrates that public matters were important and that there was a nondelegation doctrine at the Founding. Still, the limited constraints recognized and adopted by James Madison and other members of the First Congress undermine arguments for a requirement that Congress resolve all important policy questions in legislation. The general understanding recognized and applied by the Framers instead aligns most closely with today's intelligible principle requirement. This understanding refutes arguments that current nondelegation doctrine reflects demonstrable errors and must be set aside to comply with the original meaning of the Constitution.

\section{THE FiRst CONGRESS'S DELEGATION OF IMPORTANT QUESTIONS}

Congress's initial legislation established the infrastructure of a new government. This daunting task forced the First Congress to address the constitutionality of key structural attributes of executive departments. ${ }^{173}$ While early statutes creating departments such as the Department of Foreign Affairs did not implicate enumerated legislative powers, other statutes that would have delegated enumerated legislative powers to the Executive Branch presented significant constitutional concerns. A prohibition on the delegation of legislative powers was proposed in the initial round of amendments to the Constitution, ${ }^{174}$ and some members of

172 See infra Part III

${ }^{173}$ See Chabot, supra note 14, at 23-24 ("All Founding-era statutes incorporate, at least implicitly, Congress's . . . interpretations of the Constitution with respect to the particular structure enacted.").

${ }^{174}$ See Wurman, supra note 12, at 1504 ("The powers delegated by this Constitution are appropriated to the departments to which they are respectively distributed: so that ... the Executive [shall never] exercise the powers vested in the Legislative or Judicial [Branches] ...." (quoting 1 ANNALs OF CONG. 789 (1789) (Joseph Gales ed., 1834))); see also 
Congress raised delegation concerns before passing several early statutes.

In 1789, delegation concerns prevented Congress from agreeing on permanent legislation to establish the postal system. ${ }^{175}$ It settled on temporary measures that incorporated "regulations of the postoffice . . . as they last were under . . . the late Congress." 176 Nevertheless, Congress soon had to confront the delegation of other enumerated powers related to borrowing, repayment of debt, and intellectual property. ${ }^{177}$ Congress addressed all of these delegations before it returned to the issue of establishing postal roads in 1791 . The sections below discuss the First Congress's delegation of legislative powers in these areas.

\section{A. THE FIRST U.S. LAWS ON BORROWING AND REPAYMENT OF DEBT}

Repayment of the national debt was one of the greatest challenges facing the First Congress. An enormous debt loomed over the new nation, as the Constitution obligated the United States to repay pre-existing debt based on foreign and domestic loans taken out to fund the Revolutionary War. ${ }^{178}$ To add to this high "price of liberty," 179 some states also retained large debts from their wartime efforts, and state efforts to collect funds for repayment of debt

\footnotetext{
Jonathan Gienapp, The SECond CREation 133-37 (2018) (recounting debates over these amendments).

175 See MASHAW, supra note 6, at 45 ("The first attempt at bringing the Post Office under the new Constitution . . . failed because of a dispute over delegation."); see also LEONARD D. White, The Federalists: A StUdy in Administrative History 77-79 (1948) (outlining arguments against delegation of the power to create post roads); CURRIE, supra note 21, at 146-47 (same); cf. Anuj C. Desai, The Transformation of Statutes into Constitutional Law: How Early Post Office Policy Shaped Modern First Amendment Doctrine, 58 Hastings L.J. 671, 702 (2007) (noting that "a post road" was a "tangible" benefit "that every federal Representative could bring his constituents").

176 Act of Sept. 22, 1789, ch. 16, 1 Stat. 70 (expired 1790).

177 See supra notes 16-28 and accompanying text.

178 See U.S. CONST. art. VI ("All Debts contracted and Engagements entered into, before the Adoption of this Constitution, shall be as valid against the United States under this Constitution, as under the Confederation.”).

179 HAMiLTON, supra note 20.
} 
threatened to compete with federal revenue collection. ${ }^{180}$ By 1790 , the overall amount of debt was so large that current levels of revenue "could not have redeemed debt," and the United States' ability to "cover even the interest on its debt" was "dicey." 181 In addition to the assumption of state debts by the federal government, a central part of Congress's response to this debt turned on statutes that delegated power to borrow and pay debts to the Executive Branch.

1. Alexander Hamilton's Proposal. Congress initially asked Alexander Hamilton, the Secretary of the Treasury, "to devise a plan to repay the nation's debts." 182 In response, Hamilton prepared a Report Relative to a Provision for the Support of Public Credit, in which Hamilton outlined an extensive plan for refinancing state and federal debts and issuing new U.S. securities to meet current interest payments. ${ }^{183}$ In addition to assuming state debts, Hamilton recommended that the United States restructure interest payments in order to "bring the expenditure of the nation to a level with its income." 184

Hamilton urged Congress to take two further measures to support the United States' credit. First, he called on Congress to appropriate funds for repayment of the debt. To this end, Hamilton proposed that the net proceeds of the post office be placed at the disposal of a Sinking Fund Commission comprised of "the VicePresident of the United States or President of the Senate, the Speaker of the House of Representatives, the Chief Justice, Secretary of the Treasury and Attorney-General of the United States."185 The Commissioners would apply these proceeds "to the discharge of the existing public debt, either by purchases of stock in

\footnotetext{
180 Richard Sylla \& DAVID J. Cowen, AlEXANDER HAMilton on Finance, CREDit, AND DEBT 72 (2018) (noting the goal of reducing “competition for resources between the federal and state governments").

${ }^{181}$ Richard Sylla \& Jack W. Wilson, Sinking Funds as Credible Commitments: Two Centuries of US National-Debt Experience, 11 JAPAN \& WORLD ECON. 199, 208-12 (1999).

182 SYLLA \& COWEN, supra note 180 , at 69.

${ }^{183}$ HAMiLTON, supra note 20. This report was not subject to the subsequent and unsuccessful argument that a "reference to the Secretary" "on [the] subject[] of loans" was an unconstitutional "delegation of the authority of the Legislature." 3 ANNALS OF CONG. 722 (1792).

184 HAMILTON, supra note 20.

${ }^{185} I d$.
} 
the market, or by payments on account of the principal, as shall appear to them most adviseable." 186

Second, Hamilton called for new loans that would allow the United States to repay debt in a cost-effective manner. Hamilton proposed that the Sinking Fund Commissioners "be authorised, with the approbation of the President of the United States, to borrow, on their credit, a sum, not exceeding twelve millions of dollars." 187 The borrowed money would allow "a new loan, at a lower interest" to replace "part of the foreign debt."188 Additionally, Hamilton proposed that the borrowed funds be applied to "the purchase of the public debt" in the form of U.S. securities, "at the price [the debt] shall bear in the market, while it continues below its true value."189 This measure "would tend to raise the value of stock" that creditors held in the form of U.S. securities and would play a critical role in supporting the United States' credit. ${ }^{190}$ Without purchases to stabilize the value of U.S. securities, these securities might lose value, trade well below par, and limit the United States' ability to issue new debt on favorable terms. It is no surprise that Hamilton proposed delegating this power to the Commission. The timing and magnitude of purchases needed to bolster the value of U.S. securities would necessarily turn on the Commissioners' discretion in gauging fluctuating market conditions. The goals of raising the value of U.S. securities and supporting U.S. credit were not aims that could be effectuated through rigid statutory commands.

2. The First Congress Rejected a Constitutional Objection to the Delegation of Borrowing Power. Hamilton's proposal called for delegation of legislative powers enumerated in the Constitution: the power "to pay the Debts" and the power to "borrow Money." 191 Under Hamilton's proposal, a majority of the recipients of this delegated power would be commissioners who held existing offices in the Executive or Judicial Branches: the Secretary of the Treasury, the

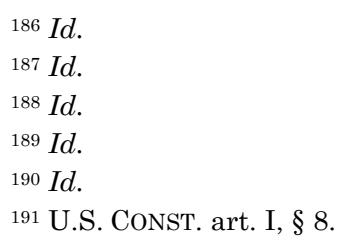


Attorney General, the Vice President, and the Chief Justice. ${ }^{192}$ Only one of five commissioners, the Speaker of the House, would belong exclusively to the legislative branch. ${ }^{193}$ Hamilton expressed no constitutional qualms about delegating legislative powers to borrow or repay debt in this fashion.

Congress did not hand over the borrowing power lightly. By the time the matter came before the House of Representatives in May of 1790, Congress had departed from Hamilton's recommended delegation to the Sinking Fund Commission and had proposed that the Secretary of the Treasury or the President be granted the power to take out new loans. ${ }^{194}$ This proposed delegation of borrowing power to executive officers drew a constitutional objection when it was debated in Congress. This May 19, 1790 debate was recorded in detailed notes taken by Thomas Lloyd, "the favored reporter," who recorded the House of Representatives' debates in shorthand. ${ }^{195}$ The First Congress's debate over delegation of borrowing power is summarized in the Annals of Congress ${ }^{196}$ and has also been noted by David Currie. ${ }^{197}$

In this debate, William Loughton Smith questioned whether a delegation of borrowing power under Article I, Section 8 would raise the same constitutional concerns as a delegation of power to establish post roads and offices (another enumerated power under Article I, Section 8):

The question on former occasion had great weight. Congress [is] vested with the power of borrowing money. The question is whether [we] can delegate that power to [the] President. The establishment of [the] post office

\footnotetext{
192 HAMilton, supra note 20.

${ }^{193} \mathrm{Id}$.

${ }^{194}$ See Lloyd's Notes, supra note 21, at 1348.

195 Tinling, supra note 16, at 519, 521. Lloyd's Notes offer the best available evidence of the May 19, 1790 debate. Id. at 530 (explaining that Lloyd's shorthand notes add "much to our knowledge of what was said"). While James Madison disputed the "accuracy" of Lloyd's notes, he still recognized that "the ideas of the speakers[] may for the most part be collected from them." Id. at 537; James Madison to Edward Everett, 7 January 1832, FoundERs ONLINE, https://founders.archives.gov/documents/Madison/99-02-02-2503.

1962 ANNALS OF CONG. 1584-85 (1790).

197 See CURRIE, supra note 21, at 73 n.143 ("Smith doubted whether Congress could delegate its power to the President at all.”).
} 
was altered on that account because the Constitution said Congress alone had the power of establishing post offices. The bill was altered. It must have more weight on this occasion. The words in the Constitution are express. The question, then, [is] whether [Congress is] authorized to delegate such important power. ${ }^{198}$

One might think the question of delegation would consume the entire debate among members of the House of Representatives, especially given Congress's earlier refusal to delegate power to establish post offices based on an identical constitutional concern. But notes of Congress's proceedings show that this was not the case.

Smith's question did not even arise as part of a motion to block delegation to the Executive Branch. Instead, James Madison had initiated a motion directed at a different structural aspect of the borrowing: the executive officer to whom power would be granted. 199 Madison feared that Congress "will by degrees introduce the (ideas) of departments into execution of laws" and moved "to strike out" the part of the bill delegating borrowing power to the "Secretary of Treasury" and to "insert 'President of the United States" in its place. ${ }^{200}$ While part of Madison's concern no doubt reflected his lack of confidence in Secretary Hamilton, ${ }^{201}$ Madison also framed his objection in constitutional terms: "In this government where the executive and legislative powers [are] separated, where a law [for] borrowing money passed, the execution referred to the head of [the] executive department." ${ }^{202}$ He questioned the committee's choice to "vary[" this arrangement by delegating power to the Secretary of the Treasury instead of the President, ${ }^{203}$ as "in that form" it would

\footnotetext{
198 Lloyd's Notes, supra note 21, at 1349 (emphasis added); see also 2 ANNALS OF ConG. 1584 (attributing Smith's positions to William L. Smith of South Carolina).

199 Lloyd's Notes, supra note 21, at 1348.

${ }^{200} \mathrm{Id}$.

201 See BERKIN, supra note 167, at 14 (describing Madison's "moral" objection to the part of Hamilton's proposal that would "pay off government certificates to current rather than original holders").

202 Lloyd's Notes, supra note 21, at 1348.

${ }^{203} I d$. Madison appeared to reject Hamilton's proposal to delegate borrowing power to the Sinking Fund Commission on the same ground. Id.
} 
"depart from" the "genius of [the] Constitution."204 Madison's opening comments reflected absolutely no concerns over a delegation of borrowing power to the Executive Branch, so long as an initial law authorizing the borrowing had passed. ${ }^{205}$ For Madison, the "importance" of the borrowing power meant only that Congress should delegate this power to the President as head of the Executive Branch: "If anything [was] of sufficient importance to justify, refer to the head of that department." ${ }^{206}$ Delegation to the President was Madison's answer to concerns about implementing a borrowing power that Madison understood to involve "great trust" and "the execution of one of the most (important laws)." 207

Other members of the House addressed Smith's concern about a delegation of borrowing power more directly. They supported the delegation of power to execute borrowing authority so long as Congress passed an initial law with some limitation on the amount to be borrowed. Benjamin Huntington emphasized that the enumerated borrowing power did not require members of Congress "to turn borrowers themselves." 208 He continued to explain that the President was "not given general authority to borrow money ad libitum," or at pleasure, "but by loan." 209 Huntington opined that the "appropriation attending the sum loaned" operated as a "limitation" on the President's borrowing power. ${ }^{210}$ Michael Stone likewise emphasized the importance of a congressionally specified limit on the President's borrowing power: the proposed legislation was constitutional because it had "not delegated[] the power to borrow money generally but [only a] particular sum."211 John Laurance's

\footnotetext{
${ }^{204}$ Id. Madison recognized that the President would "make[] use of [the] Secretary as the agent" in borrowing. Id.

${ }^{205} I d$. at 1350 (statement of Madison) (noting obliquely that "[t]he gentlemen think that because Congress has power to borrow money-When the law passed, the execution [is now] within the executive department"); see also Rappaport, supra note 6, at 365 (noting that in England, "Parliament often provided [the King] with discretion to determine whether to borrow, how much to borrow, and on what objects to use the funds").

206 Lloyd's Notes, supra note 21, at 1350.

${ }^{207} I d$. at 1354 .

${ }^{208} I d$. at 1351.

${ }^{209}$ Lloyd's Notes, supra note 21, at 1351.

${ }^{210} I d$. Elbridge Gerry also urged Congress to "confine the loan solely to [the] purpose of paying off the debt," $i d$. at 1355 , although his statements appeared to reflect a normative interest in avoiding more debt.

${ }^{211} I d$. at 1349 .
} 
comments focused on the President's general constitutional power to execute laws passed by Congress, and he opined that it was "[o]nly necessary to say borrow" in legislation to allow the President to claim broad responsibility and "see it executed." 212 While these statements did not suggest Congress had to decide much, a cap on the amount to be borrowed would ensure that Congress delegated some quantum of power less than its whole borrowing power under Article I, Section 8. ${ }^{213}$ Thus, the limitation would prevent Congress from completely undoing the initial allocation of powers established by Article I.

Taken as a whole, these comments support the delegation of borrowing power with some cap on the amount borrowed. They do not suggest an understanding that the Constitution required Congress to resolve all major questions surrounding the borrowing power or eliminate executive discretion in its enabling legislation. No one proposed statutory language to limit executive discretion by having Congress specify critical parameters such as limits on the interest rate, discounts or commission fees commonly taken out as a percentage of the loans, or which foreign loans to repay first.

Much of the debate acknowledged that the law would award great discretion to the Executive Branch and focused on whether the proposed legislation should vest the greatest possible amount of discretion by assigning the borrowing power directly to the President. Thomas Fitzsimons questioned a direct delegation to the President on the ground that it would be "easier to call [the] officer of treasury to account than the President if he should mismanage."214 Additionally, Fitzsimons emphasized that the treasury department was "bound by laws." 15 Presumably, he referred to ex post and structural controls established by the Treasury Secretary's duties to "report" his actions to Congress and to follow a specified process to grant "warrants for monies to be issued from the Treasury."216

Theodore Sedgwick also contemplated the President's ability "to apply the sum to arrears and installments in such [a] manner as his

\footnotetext{
${ }^{212} I d$. at 1352.

${ }^{213}$ See supra note 60 and accompanying text.

${ }^{214}$ Lloyd's Notes, supra note 21, at 1349.

${ }^{215} I d$.

${ }^{216}$ Act of Sept. 2, 1789, ch. 12, § 2, 1 Stat 65, 66 .
} 
discretion thinks fit" and questioned whether the President would choose to report "the minute detail" of these actions. ${ }^{217}$ Representative Samuel Livermore focused on the importance of issuing out borrowed money through the Treasury, as this Department had "officers established for every step of this business" and could ensure that the funds were "issued out according to the law."218 William Smith, who appeared to back off of his absolute objection to any delegation of borrowing power, suggested that Congress was vested with "power, [to] declare the terms of loan, and carry out through the proper officer." ${ }^{119}$ In making this point, Smith emphasized the Treasury's greater accountability to Congress: "The treasury [has] to report to Congress[,] but [Congress has] no control over the President unless we impeach him." ${ }^{220}$ A majority of these objections thus focused on the greater accountability that reporting and other structural controls on disbursement would grant to Congress.

James Madison maintained that the President would still retain sufficient accountability and reporting duties under the existing constitutional framework. Madison argued that the President would be "responsible" to Congress because he was "impeachable" and would therefore "be glad to discuss" his actions with Congress. ${ }^{221}$ Madison also argued that the Constitution favored the vesting of important matters such as borrowing in the President, based on "the practice of parliament . . . to empower His Majesty to borrow[,]" but noted "diversity of opinion" on this issue. ${ }^{222}$ Some members of Congress supported Madison's motion based on the related understanding that the President "would necessarily be the officer and have the supreme control under the Constitution, not under the law." 223

In addition to constitutional arguments, some members of the House emphasized practical benefits of delegation to the President,

\footnotetext{
${ }^{217}$ Lloyd's Notes, supra note 21, at 1349-50.

$218 \mathrm{Id}$. at 1353.

${ }^{219} I d$. at 1354 .

${ }^{220} \mathrm{Id}$. at 1354 .

${ }^{221} I d$. at 1350. Madison assumed that Congress could "request information" about moneys loaned by the President, and that "it would be [a] proper ground of impeachment" if the President refused the request. $I d$.

$222 I d$. at 1354.

${ }^{223} I d$. at 1353 (statement of Bland).
} 
noting that his direct role might "add to the respectability of the loan" 224 and help the United States "get money on easy terms."225 Other members disagreed that the choice of executive officer posed a "Constitutional question." 226 According to Sedgwick, "[a]s Congress [is] authorized to borrow money, Congress can determine the instrument by which [to] execute the power. It is nothing more than [a] question of convenience or inconvenience." ${ }^{227}$ Sedgwick and others also favored the greater structural control that Congress retained over the Secretary of the Treasury. 228

Madison's motion ultimately prevailed, and the House decided to vest borrowing power directly in the President. ${ }^{229}$ Thirty-two Representatives voted in favor of this amendment. ${ }^{230}$ It is unclear how much of this vote was based on Madison's constitutional argument as opposed to the practical considerations that weighed in favor of a delegation to the President. With respect to the constitutional objection to delegation, however, the decision to vest borrowing power in the President plainly rejected Smith's initial objection to any delegation of this power whatsoever. Congress's decision was also inconsistent with Smith's further understanding that Congress should delegate only more limited executory duties to a lesser officer positioned to "carry out" Congress's wishes. ${ }^{231}$ After hesitating to delegate the establishment of post roads and offices to the Executive Branch, the First Congress delegated a different legislative power to the President: the power to borrow money. The majority's decision to vest borrowing power in the President rather than the Secretary of the Treasury also meant it had chosen the structure awarding the Executive Branch a greater amount of discretion. And James Madison referred to this discretion as involving "a great trust" in "the execution of one of the most (important laws)."232

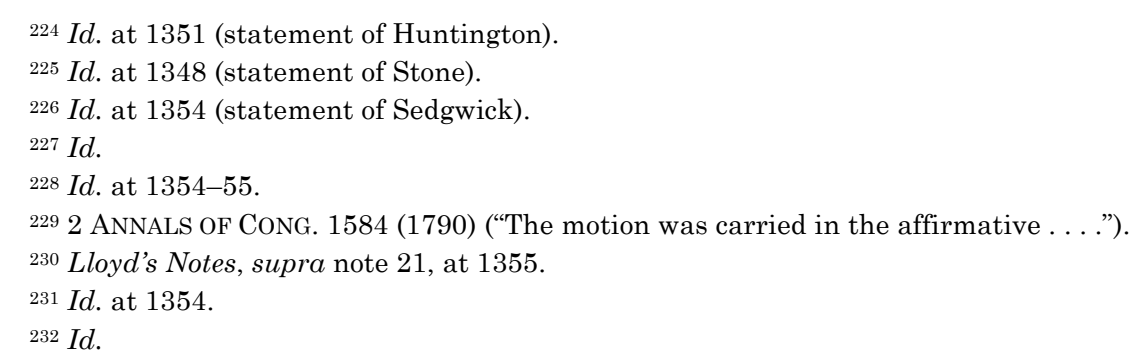


Not everyone agreed that Congress should grant the President so much power, and the Representatives who opposed delegation to the President included Smith, Sherman, Livermore, and Sedgwick. ${ }^{233}$ But even these Representatives did not press Smith's general objection to a delegation of legislative powers, and Smith himself also seemed to drop this point and instead focused on the relative accountability of the Secretary of the Treasury and the President to Congress. ${ }^{234}$ Sherman, Livermore, and Sedgwick's primary objections to the President's discretion also turned on the greater accountability inherent in the Secretary's duty to report borrowing and disbursement activities to Congress after the fact. ${ }^{235}$ Smith appeared to be the only Representative to suggest that Congress should be the one to "declare the terms of [a] loan," and even then, he emphasized the importance of ex post controls that required "treasury to report to Congress." 36 None of the Representatives who opposed a broad delegation of discretionary authority to the President suggested that Congress should avoid the problem by passing a more detailed law or dictating limits on key terms in order to cabin the President's discretion. The notion that the Constitution banned capacious statutory language or legislation that handed off major national policy questions to the Executive Branch was not even a well-developed minority position in the First Congress's lengthy debate on this issue.

The constitutional objection to delegation was ultimately dismissed by a majority of the House when it voted in favor of a broad delegation of borrowing power to the President. ${ }^{237}$ One cannot reconcile the legislation that delegated borrowing power to the President with an important subjects theory of delegation. Arguments in favor of delegation recognized that the President would necessarily have broad discretion to determine key terms of consequential loans and that Congress need only cap the total amount borrowed to satisfy its constitutional requirements. The First Congress's understanding is close to today's intelligible

2332 ANNALS OF CONG. 1584 (1790) (listing representatives who "were in favor of the clause as it stood in the bill").

${ }^{234}$ Lloyd's Notes, supra note 21, at 1354.

${ }^{235}$ Id. at $1349-53$.

236 Id. at 1354 .

2372 ANNALS OF CONG. 1584 (1790). 
principle requirement. As noted below, early Congresses repeatedly delegated broad discretion over important subjects in subsequent debt legislation.

3. The Borrowing Legislation Delegated Broad Discretion to Determine Important Terms of Loans. Legislation passed by the First Congress granted the Executive Branch broad discretion to resolve important questions related to borrowing money and paying debts. In its August 4, 1790 "Act Making Provision for the [payment of the] Debt of the United States," Congress addressed foreign debt. $^{238}$ The Act authorized the President to take out up to $\$ 12$ million in "new loans" for payment of "arrears of interest" and installments due on "the principal" of foreign debt, and "if it can be effected upon terms advantageous to the United States . . . paying off the whole of the said foreign debt." 239 The Act also authorized the President "to cause to be made such other contracts respecting the said debt as shall be found for the interest of the said States." ${ }^{440}$ The Act established only two parameters for the President to follow when taking out loans to pay off or refinance foreign debt: First, any "sum or sums" borrowed could "not exceed[] ...twelve million" dollars in total. ${ }^{241}$ Second, repayment of any "engagement [or] contract" must occur "within fifteen years." 242

Otherwise, the President had extremely broad discretion to borrow any amount ranging from $\$ 0$ to $\$ 12$ million. The Act set no parameters for interest rates on loans designed to fund payments of principal and interest on pre-existing loans. It instructed the President to obtain only "terms advantageous to the United States" for any loan "paying off the whole of the said foreign debt." ${ }^{443}$ The Act was completely silent on the related question of discounts, or "commission fees" as they were known at the time, which could range from $3.5 \%$ to $9 \%$ of the amount borrowed. ${ }^{244}$ Professors Mortenson and Bagley also point out that these provisions lacked

\footnotetext{
238 Act of Aug. 4, 1790, ch. 34, 1 Stat. 138 (obsolete) (alteration in original).

${ }^{239}$ Id. $\S \S 1-2,1$ Stat. at 139 .

${ }^{240} I d . \S 2$.

${ }^{241} I d$.

${ }^{242} I d$.

${ }^{243} I d$.

244 See James C. Riley, Foreign Credit and Fiscal Stability: Dutch Investment in the United States, 1781-1794, 65 J. AM. HIST. 654, 659 tbl.1 (1978) (listing commission fees for Dutch loans to the United States).
} 
specific instruction on "which debts to pay first" and whether to prioritize repayment or restructuring. ${ }^{245}$ Given Congress's earlier consideration of the constitutionality of delegating borrowing power to the Executive Branch, and common knowledge of unavoidable borrowing terms such as interest rates and commission fees for existing loans, the statute plainly delegated the President power to decide important terms of these loans.

Congress's decision to allow new loans of up to $\$ 12$ million gave the President vast discretion over both the total amount to be borrowed and the terms of the loans. In general, a law that "merely state[s] the maximum amount that the executive may" borrow but does "not indicate how much between zero and that amount the executive must" borrow leaves broad discretion over the amount loaned. ${ }^{246}$ The sizeable outer limit on permissive borrowing, up to $\$ 12$ million, magnifies the scope of the President's discretion. While raw figures from 1790 do not afford a ready comparison to sums that might reflect significant portions of today's national economy, at the time, $\$ 12$ million was an immense sum. It was on the scale of the $\$ 15$ million that the United States would spend to double the size of the United States in the 1803 Louisiana Purchase. ${ }^{247}$ When $\$ 12$ million is considered as a percentage of the gross domestic product (GDP) in 1790, and then converted to an equivalent percentage of the GDP today, the total amount that the President could borrow in current terms would be equivalent to $\$ 1.286$ trillion. ${ }^{248}$

Even the potential variation in annual interest or discount rates on $\$ 12$ million afforded the President great discretion over the amount of interest and fees that the United States would have had to incur to obtain new loans. As mentioned above, the Act did not address commission fees, failed to specify an upper limit for the interest rate, and at most presumed that "advantageous" terms for

\footnotetext{
245 Mortenson \& Bagley, supra note 11, at 344-45.

${ }^{246}$ Rappaport, supra note 6, at 317 (noting the similar policy discretion imposed by “"permissive' appropriations" that allow the Executive to "spend no more than $X$ dollars").

${ }_{247}$ See The Louisiana Purchase, supra note 22 (listing the price of the Louisiana Purchase as $\$ 15$ million).

248 This figure is based on an estimate that $\$ 12$ million represented $6 \%$ of the nominal U.S. GDP in 1790 , which then stood at $\$ 189$ million. In current terms, $\$ 1.286$ trillion is $6 \%$ of the $\$ 21.43$ trillion nominal U.S. GDP from 2019. Louis Johnston \& Samuel H. Williamson, What Was the U.S. GDP Then?, MEASURINGWORTH, http://www.measuringworth.org/usgdp/ (last visited Sept. 20, 2021).
} 
refinancing would result in a rate lower than those the United States was currently paying in interest. ${ }^{249}$ It remained up to the President to determine how advantageous the new interest rate would be. If the President obtained $\$ 12$ million in loans at a rate of $5 \%$ instead of $4 \%$, for example, ${ }^{250}$ the United States would owe an additional $1 \%$, or $\$ 120,000$ in annual interest. When this amount is converted into a percentage of today's GDP, it is equivalent to $\$ 12.86$ billion. $^{251}$ Both the discretion to borrow up to $\$ 1.286$ trillion and to incur an additional $\$ 12.86$ billion in interest (in today's dollars) must be considered important. ${ }^{252}$

The President's execution of borrowing power further illustrated how many decisions Congress left up to the Executive Branch. As was expected, after Congress vested borrowing power in President Washington, the President enlisted Alexander Hamilton as his agent in obtaining new loans. ${ }^{253}$ Hamilton had already discussed the possibility of a new loan with Dutch bankers earlier in the year, as both the United States and the Dutch were eager to refinance the United States' substantial debt to France. ${ }^{254}$ On August 28, 1790, Hamilton wrote the Dutch bankers to inform them of the new loans authorized by Congress: "the Legislature of the United States . . . passed two Acts" by which "they empower the President to cause to be borrowed on account of the United States Fourteen Millions of Dollars." 255 The power to borrow up to $\$ 14$ million reflected loans

\footnotetext{
${ }^{249}$ Act of Aug. 4, 1790, ch. 34, § 2, 1 Stat. 138, 139.

250 See HAMILTON, supra note 20 (predicting that interest rates would "fall at least as low as five per cent" and may also "sink still lower, probably to four" percent over time).

251 This figure reflects $6 \%$ of the U.S. GDP, based on an estimate that $\$ 120,000$ represented $6 \%$ of the nominal U.S. GDP in 1790. See supra note 248.

252 This is over a hundredfold greater than the threshold for "major rules" under the Congressional Review Act, which provides for congressional review of rules with "an annual effect on the economy of $\$ 100,000,000$.” 5 U.S.C. $\S 804(2)(\mathrm{A})$.

${ }^{253}$ Letter from George Washington to Alexander Hamilton (Aug. 28, 1790), in Washington Papers, FoundERs ONLINE, https://founders.archives.gov/documents/Washington/05-06-020167 (instructing Hamilton to borrow "on the best terms which shall be found practicable (and within the limitations prescribed by Law as to time of repayment and rate of interest)").

${ }^{254}$ SYLLA \& COWEN, supra note 180, at 105-06 (noting that part of the French loans were funds provided by Dutch bankers "with guarantees provided by the [K]ing," and the early phases of the French Revolution caused the King to seek quick repayment of these debts).

${ }^{255}$ Letter from Alexander Hamilton, Sec'y of the Treasury, Treasury Dep't, to Wilhem and Jan Willink, Nicholaas and Jacob Van Staphorst, and Nicholas Hubbard (Aug. 28, 1790) [hereinafter Hamilton's Letter], https://founders.archives.gov/documents/Hamilton/01-06-02-
} 
authorized in two separate acts: the Act of August 4, 1790, which authorized the President to borrow up to $\$ 12$ million to refinance and pay interest on foreign debt, ${ }^{256}$ and the Act of August 12, 1790, which authorized the President to borrow up to $\$ 2$ million to repay domestic debt. ${ }^{257}$ Hamilton's letter also explained that the President had "committed" the "execution" of borrowing power to him and included a copy of the President's commission to Hamilton. ${ }^{258}$

Hamilton agreed to key terms of this initial loan from the Dutch bankers. The bankers would provide a loan in the amount of "three Millions of florins" 259 (roughly equivalent to $\$ 1.2$ million) at an interest rate of $5 \%$, plus $4.5 \%$ in commission fees. ${ }^{260}$ Hamilton requested that the loans conform to the fifteen-year reimbursement period established by the Act of August 4, 1790. ${ }^{261}$ Hamilton also expressed his desire for, but did not insist on, business "so regulated as to give it the form of two loans" and to allocate separate funds to the distinct foreign and domestic loans authorized by the Acts of August 4 and August 12, 1790. ${ }^{262}$ The decision not to insist on separate loans would later subject Hamilton to congressional scrutiny. ${ }^{263}$ Hamilton reported to Congress that, due to the "very nature of the case," he felt that a "considerable latitude of discretion" attended the loans he took out on the President's behalf. ${ }^{264}$

The borrowing power that Congress had awarded Washington and Hamilton was so vast that it afterward raised questions about Hamilton's compliance with the borrowing laws. In 1791, Congress passed a further Act to clarify that commission fees of $4.5 \%$ on the

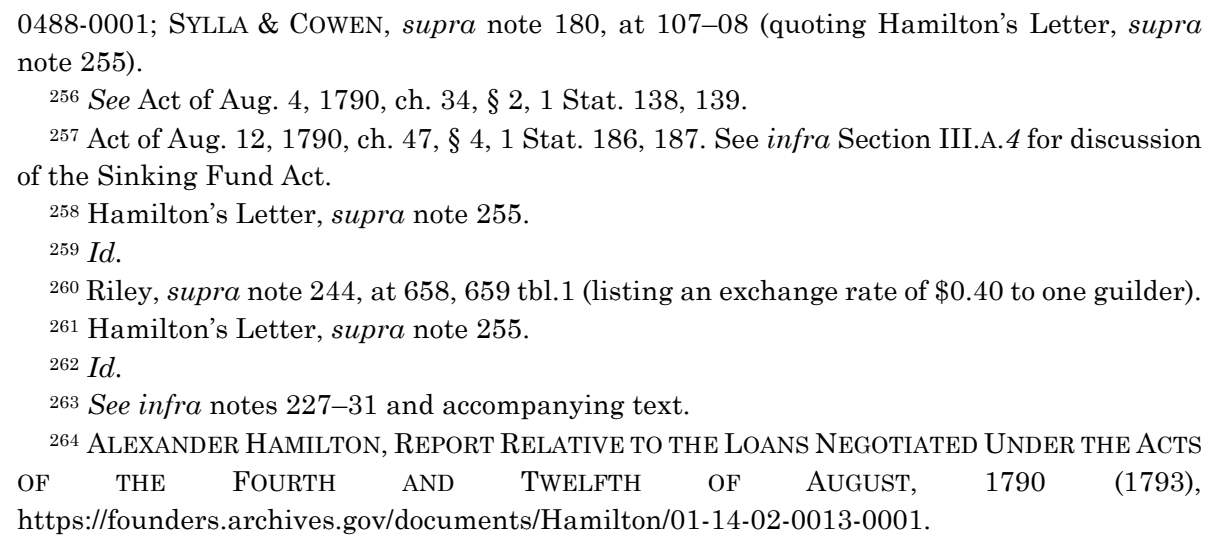


August 28 loan and future loans under the August 12 Act were "within the true intent and meaning" of the Act and its provision "limit[ing] the rate of interest to five per centum." ${ }^{265}$ Presumably, this provision was intended to assure future creditors that loans including such commission fees would qualify for the August 12 Act's appropriations of sums and guarantee of repayment. ${ }^{266}$

In other instances, the broad discretion conferred by the borrowing laws allowed Hamilton's enemies to mount a political attack against him. Thomas Jefferson connived an objection that was taken up by James Madison and William Giles in Congress. ${ }^{267}$ In his September 9, 1792 letter to President Washington, Jefferson complained of Hamilton as "the man who has the shuffling of millions backwards and forwards from paper into money and money into paper, from Europe to America, and America to Europe." ${ }^{268}$ In 1793, Giles submitted to the House of Representatives allegations that Hamilton violated the law in dispersing proceeds of loans under the Acts of August 4 and August 12, 1790. ${ }^{269}$ As recounted by Leonard White, Giles charged Hamilton with misappropriating "part of the funds borrowed under the act of August 4 . . to buy a portion of the domestic debt," when the Act authorized repayment of foreign debt only. ${ }^{270}$

James Madison spoke at length to support the charges against Hamilton. In addition to arguing that Hamilton had allocated more funds to the Sinking Fund Commission than allowed by statute, Madison argued that Hamilton had violated the President's instructions when taking out loans. ${ }^{271}$ Madison claimed that President Washington's written commission to Hamilton granted only the authority to borrow funds intended to repay foreign debt. ${ }^{272}$

265 Act of Mar. 3, 1791, ch. 25, 1 Stat. 218, 219.

266 Hamilton previously emphasized the creditworthiness demonstrated by the "actual appropriation" of "funds for payment of the Interest." Hamilton's Letter, supra note 255.

267 WHITE, supra note 175 , at 352 .

${ }^{268}$ Letter from Thomas Jefferson to George Washington (Sept. 9, 1792), https://founders.archives.gov/documents/Jefferson/01-24-02-0330.

269 See 3 ANNALS OF CONG. 900 (1793) (proposing that Washington fire Hamilton).

270 WHITE, supra note 175 , at 353.

271 See 3 ANNALs of CONG. 939 (1793) ("[I]f the moneys drawn had been carried to the Sinking Fund, the limited sum of $\$ 2,000,000$ would have been exceeded . ..."); id. (referencing "the contradictory steps" that Hamilton took against the President's instructions).

${ }^{272} I d$. at $935-36$. 
The Dutch loan that Hamilton agreed to on August 28, 1790 arguably exceeded this commission by taking out a single loan for money that would repay both the foreign and domestic debt. ${ }^{273}$

Madison emphasized that Hamilton's discretion to borrow money ought to have been sharply limited to the loans expressly authorized by the President, who under the Acts of August 4 and August 12, 1790 possessed far greater discretion to borrow money than the Secretary of the Treasury. ${ }^{274}$ Madison reasoned that Hamilton had only limited statutory authority as Secretary of the Treasury. ${ }^{275}$ As a result, Hamilton did not automatically share the "great" power reflected in the Acts giving the President "latitude as to the terms and contracts" for loans amounting to the vast sum of $\$ 14$ million. ${ }^{276}$ Other members of the House questioned Madison's censure, noting that the President's complete instructions to Hamilton may not have been disclosed and that the President made no "objections to the conduct of his agent."277

Madison's case foundered on the inability to show that Hamilton had disobeyed the President, and a majority of the House ultimately exonerated Hamilton. ${ }^{278}$ The need to base the charges against Hamilton on his failure to follow presidential instructions further illustrates the great discretion conferred by the borrowing laws. Hamilton had not violated the minimal requirements of the borrowing laws, and the legality of his actions was ultimately determined by the President rather than terms set by Congress.

4. The Sinking Fund Legislation Delegated Key Monetary Policy Decisions. Congress effectuated another key part of Hamilton's proposal in a second statute designed to fund repayment of domestic debt. This statute also awarded broad discretion to the Executive Branch. In its August 12, 1790 Act, Provision for Reduction of the Public Debt, Congress empowered the Sinking Fund Commission

\footnotetext{
${ }^{273} I d$. at 937 (asserting that Hamilton diverted the loan for "a purpose different from that specified and required by his instruction").

${ }_{274}$ See id. at 942 ("[T]he authority of the Secretary, in executing the loans, and the appropriation of them, must be derived from the President ....”).

$275 \mathrm{Id}$. at 941.

${ }^{276} I d$. at 942 . Madison doubted "whether an equal power will ever be committed to a successor" but accepted the delegation to President Washington. Id.

277 Id. at 952.

${ }^{278} I d$. at $956-64$.
} 
and the President to pay the debt. ${ }^{279}$ The Sinking Fund Commission was a five-member board comprised of the Secretary of the Treasury (Alexander Hamilton), Secretary of State (Thomas Jefferson), President of the Senate/Vice President (John Adams), the Attorney General (Edmund Randolph), and the Chief Justice (John Jay). ${ }^{280}$ Rather than requiring a formulaic repayment of debt, this Act granted the Sinking Fund Commission and the President discretion to "purchase ... debt of the United States"-in the form of U.S. securities- "in such manner, and under such regulations as shall appear to them best calculated to fulfill the intent of this act." 281

As explained in the Act, Congress intended the Commission's purchases to both "effect a reduction of the amount of the public debt" and benefit "creditors of the United States, by raising the price of their stock." 282 The Commission's and President's power to carry out purchases fulfilling these dual mandates was capped only by the requirement that purchases of debt, in the form of U.S. securities, be at "market price, if not exceeding the par or true value thereof." 283 In other words, the Commission could support creditors who purchased U.S. securities only to the point of ensuring that they would receive the par or true value of these debt instruments. Congress granted the Commission and President wide discretion over the magnitude of purchases by funding them through a surplus of revenues based on import duties. ${ }^{284}$ It also allowed the President to borrow an additional $\$ 2$ million to support further purchases. ${ }^{285}$

The Act afforded the Commission tremendous discretion to decide when and in what amount to enter the market and buy U.S. securities. ${ }^{286}$ Any purchase of U.S. securities would serve the Act's first goal of reducing the amount of debt, but the second goal of raising the value of U.S. securities required the Commission to exercise great discretion. The Commission had to apply expert financial judgment to determine the timing and magnitude of

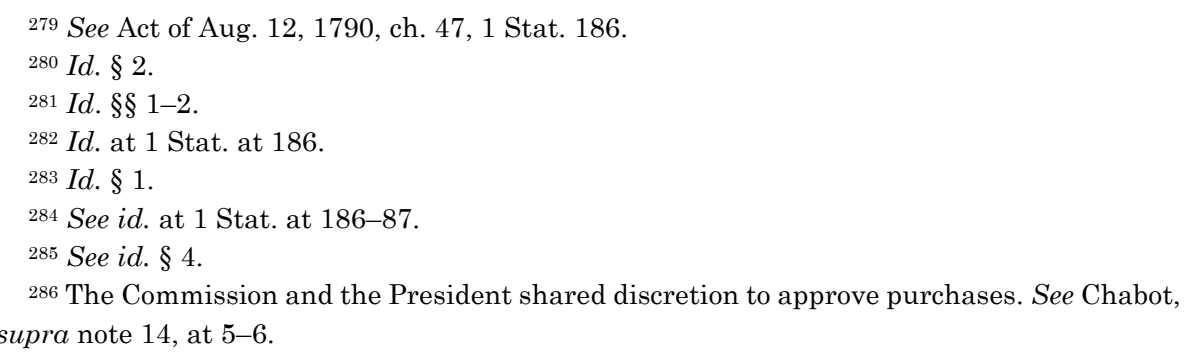


purchases needed to prop up the value of U.S. securities. ${ }^{287}$ Congress did not specify particular market conditions or a percentage of loss in value of U.S. securities required for the Commission to intervene, nor did it suggest the magnitude of purchases that would amount to an appropriate intervention. The Commission's policy decisions on these matters had enormous implications for the national economy and private creditors who held these securities. If the Commission failed to make a timely or sufficient intervention, jittery investors might flood the market with devalued U.S. securities and jeopardize the United States' ability to obtain future credit through sales of additional securities.

The Sinking Fund Commission's open market purchases of debt, in the form of U.S. securities, revealed disputes over discretionary spending decisions and intractable policy disagreements between Hamilton and Jefferson. The Commission began to expand open market purchases in a manner designed to stabilize the value of U.S. securities in 1791, with authorization of purchases up to $\$ 400,000.288$ By 1792 , a steep market crash and financial panic created "an episode of crucial economic and political importance" and called out for more Commission purchases to stabilize the market. ${ }^{289}$ Hamilton sent the Treasurer to the market to purchase additional government securities with funds that the Commission had approved earlier. ${ }^{290}$ While these purchases were designed to "maintain or restore the price of Government securities in the face of the panic," 291 Hamilton did not think they were sufficient. He

287 See Barry Sullivan \& Christine Kexel Chabot, The Science of Administrative Change, 52 ConN. L. REV. 1, 79 (2020) (discussing how expert judgment inheres in the Federal Reserve's open market purchases).

288 Meeting of the Commissioners of the Sinking Fund, [15 August 1791], Founders ONLINE, https://founders.archives.gov/documents/Hamilton/01-09-02-0045.

289 Richard Sylla, Robert E. Wright \& David J. Cowen, Alexander Hamilton, Central Banker: Crisis Management During the U.S. Financial Panic of 1792, 83 BUS. HIST. REv. 61, 61 (2009).

290 See Letter from Alexander Hamilton to John Adams (Mar. 20, 1792), https:/founders.archives.gov/documents/Hamilton/01-11-02-0124 (noting the Treasurer's authority to purchase securities); Letter from Alexander Hamilton to Thomas Jefferson (Mar. 20, 1792), https://founders.archives.gov/documents/Jefferson/01-23-02-0263 (same).

${ }^{291}$ Letter from Alexander Hamilton to John Adams, supra note 290, at n.1. 
urged the Commission to approve further purchases of U.S. securities without delay. ${ }^{292}$

The facts of the financial panic were not in dispute, but the Commissioners disagreed over both the law and policy dimensions of the appropriate response. As the market prices of U.S. securities continued to plummet, the Commissioners disagreed whether to purchase these securities at prices that seemed to exceed their rapidly declining worth. ${ }^{293}$ Four of the Commissioners met in Philadelphia and split $2-2$ on this issue. ${ }^{294}$ Only Hamilton and Adams agreed to immediate purchases of devalued U.S. securities, ${ }^{295}$ while Jefferson and Randolph would have waited for the fifth Commissioner, Chief Justice John Jay, to cast the deciding vote. ${ }^{296}$

Chief Justice Jay could not vote because he was tending to judicial duties in New York. ${ }^{297}$ The Commissioners told Jay that their "difference of opinion" respected "the construction of their authority under the Act" 298 and whether purchases of devalued securities at market prices would unlawfully exceed "the par or true value" of the securities. ${ }^{299}$ In response, Jay offered to write an opinion on this disputed "law [q]uestion" and send it to the Commission "[e]xpress." 300 The need "to operate immediately, if at all” led Hamilton, Adams, and Randolph to accept Jay's offer to provide a written opinion. ${ }^{301}$ At the time, it was doubtful that Jay's

\footnotetext{
${ }^{292}$ See Sylla \& Cowen, supra note 180, at 78 (recounting additional purchases urged by Hamilton).

${ }_{293}$ See Sylla et al., supra note 289, at 79 (noting Jefferson's objection "that the 'true values' of [certain securities] were lower than their market prices").

294 See Letter from John Adams to John Jay n.1 (Mar. 21, 1792), https://founders.archives.gov/documents/Hamilton/01-11-02-0126 ("The four trustees of the sinking fund . . . hav[e] been divided ...." (quoting Letter from Edmund Randolph to John Jay (Mar. 21, 1792))).

${ }^{295}$ See id.

296 See Sylla et al., supra note 289, at 78 (noting Jefferson and Randolph's desire "to delay action until Jay returned" to vote).

${ }^{297}$ See Letter from John Jay to Alexander Hamilton (Mar. 23, 1792), https://founders.archives.gov/documents/Hamilton/01-11-02-0141.

${ }^{298}$ Letter from John Adams to John Jay, supra note 294.

299 Act of Aug. 12, 1790, ch. 47, § 1, 1 Stat. 186.

${ }^{300}$ Letter from John Jay to Alexander Hamilton, supra note 297.

301 See Meeting of the Commissioners of the Sinking Fund [26 March 1792], Founders ONLINE, https://founders.archives.gov/documents/Hamilton/01-11-02-0155.
} 
legal opinion would resolve the Commissioner's dispute. Jefferson dissented from the decision to seek Jay's written opinion at all, ${ }^{302}$ and observers suggested that "Mr. Jay's opinion . . . will not decide the business - that his vote must be viva, voce." 303

Chief Justice Jay's legal opinion operated as a Founding-era precursor to "step one" of modern-day Chevron analysis, which asks whether Congress has "directly spoken to the precise question at issue" by ruling out a proposed agency action as a matter of law. ${ }^{304}$ In particular, the Chief Justice addressed whether the term "true value" created a purchasing constraint in addition to the requirement that purchases not exceed par value. ${ }^{305}$ The grammatical placement of the conjunction "or" after "par" and before "true value" led him to conclude that the meaning of "or" was "precisely equivalent to" phrases such as "that is to say; in other words, to wit." ${ }^{06}$ Thus, Chief Justice Jay opined that the phrase "true value" did not create an additional constraint on the Commission's purchases and that the Act's restrictions operated only to exclude purchases in which the market price exceeded par value. ${ }^{307}$ The Chief Justice's analysis confirmed that the Commission retained broad discretion to make the open market purchases urged by Hamilton.

The legal issues determined by Jay's March 31, 1792 letter resolved some but not all of the Commissioners' disagreement. After Jay issued this letter, Edmund Randolph joined Hamilton and Adams to cast the deciding and necessary third vote to approve up to $\$ 100,000$ in additional purchases by the Sinking Fund Commission. ${ }^{308}$ But Jay's opinion established only the upper limits of the Commission's authority and never resolved the broader policy

\footnotetext{
302 See id. ("Resolved, (the Secretary of State dissenting) [t]hat the said question be stated in writing, and forwarded to the Chief ....”).

${ }^{303}$ Letter from Philip Livingston to Alexander Hamilton (Mar. 24, 1792), https://founders.archives.gov/documents/Hamilton/01-11-02-0144 (recounting the opinions of Schuyler and Livingston).

${ }^{304}$ Chevron U.S.A., Inc. v. Nat. Res. Def. Council, Inc., 467 U.S. 837, 842 (1984).

${ }^{305}$ Letter from John Jay to Commissioners of the Sinking Fund (Mar. 31, 1792), https://founders.archives.gov/documents/Hamilton/01-11-02-0175.

${ }^{306} I d$.

${ }^{307} I d$.

308 Meeting of the Commissioners of the Sinking Fund [4 April 1792], Founders OnLINE, https://founders.archives.gov/documents/Hamilton/01-11-02-0187.
} 
dispute between Jefferson and other members of the Commission. Notwithstanding Jay's opinion letter, Jefferson continued to dissent from the Commission's disbursal of $\$ 100,000$ for additional purchases, approved on April 4, $1792,{ }^{309}$ and from its further disbursal of up to $\$ 200,000$, approved on April 12, $1792 .{ }^{310}$ A manuscript styled "Dissenting Opinion on the Sinking Fund" described the "Secretary of State" as "continuing to dissent from" estimates of certain securities' "true value" as reflecting purchase prices approved by the Commission on April 12.311 Jefferson's continued opposition to what were arguably inflated purchase prices has been explained as an objection to an unfair windfall to speculators $^{312}$ or a desire "to injure Hamilton" and the "financial revolution he led." 113 Whatever the precise reasons for Jefferson's continued objections, they were not quelled by the Chief Justice's legal analysis. Jefferson would not have used open market purchases to provide U.S. creditors with the same level of support that other members of the Sinking Fund Commission found appropriate in this case.

As illustrated by this episode, the August 12 Act afforded the Commission and President broad discretion to implement monetary policy. Congress authorized these executive actors to invest millions of dollars in purchases of U.S. securities when, in their judgment, the timing and magnitude of their purchases would check the

\footnotetext{
${ }^{309}$ See id. ("[T]he Secretary of State dissents.").

310 See Meeting of the Commissioners of the Sinking Fund, [12 Apr. 1792], Founders ONLINE [hereinafter April 12 Sinking Fund Meeting], https://founders.archives.gov/documents/Hamilton/01-11-02-0225 ("From so much of the above resolution as relates to the purchase of three per cent. and deferred stock, the Secretary of State dissented.").

311 See Dissenting Opinion on the Sinking Fund, [12 Apr. 1792?], FOUnDERS OnLINE, https://founders.archives.gov/documents/Jefferson/01-27-02-0786 (disputing the estimate of "three percents at more than 10/ the pound" (footnote omitted)). The Commission's April 12 resolution approved purchases of three percent at prices up to "twelve shillings in the pound"- the level it had earlier applied on August 15, 1791. Meeting of the Commissioners of the Sinking Fund [15 August 1791], Founders ONLINE, https://founders.archives.gov/documents/Hamilton/01-09-02-0045; April 12 Sinking Fund Meeting, supra note 310 (approving new purchases "on the principles of the resolution of the 15th day of August, 1791").

312 See Dissenting Opinion on the Sinking Fund, supra note 311 (noting purchase policies that "the Virginian evidently regarded as a prop to speculators").

${ }^{313}$ Sylla et al., supra note 289 , at 79 .
} 
declining market value of securities held by creditors of the United States. Noted economic historians credit Hamilton's open market purchases as being part of a series of "central-banking crisismanagement techniques" that "successfully contained" a major financial panic in $1792 .{ }^{314}$ The 1792 crash threatened to "destroy[] America's financial revolution" and "the country's relative prosperity." 315 The monetary policies implemented by the Sinking Fund Commission's discretionary open market purchases helped prevent this catastrophic outcome. ${ }^{316}$

5. Congress Continued Granting the Executive Broad Discretion to Pay Debt and Borrow Funds for "Public Purposes." Congress continued to grant broad discretion over borrowing and open market purchases to repay debt in subsequent legislation. Despite Congress's concerns over Hamilton's management of borrowed funds under the Acts of August 4 and August 12, it continued to award the Executive great discretion over funds borrowed for "public purposes" in subsequent legislation. ${ }^{317}$ In a 1794 Act, Congress authorized the President to borrow a "sum not exceeding one million of dollars" if, "in his opinion, the public service shall require it." 318 The Act did not address commission fees, allowed for "interest not exceeding five per centum," provided that the loans were "reimbursable at the pleasure of the United States," and allowed the borrowed funds "to be applied to such public purposes, as are authorized by law." 319 Congress passed a similarly openended authorization for a loan of up to $\$ 2$ million in December of that year. ${ }^{320}$

Congress also continued to award discretionary power to the Sinking Fund Commission in legislation passed in 1792 and 1795. The 1792 legislation continued the Commission's power to manage debt through open market purchases: Congress again authorized the Commission to "purchase the debt of the United States, at its

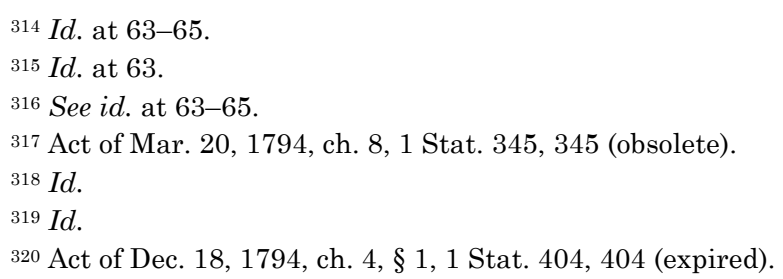


market price, if not exceeding the par or true value thereof."321 While the 1792 legislation limited the Commission's earlier and controversial purchasing discretion by requiring it to obtain the "lowest price" that could "be obtained by open purchase," 322 Congress still left the overall amount and timing of purchases up to the Commission. ${ }^{323}$ By 1795, the Commission's open market purchases had enjoyed so much success that Congress no longer needed to worry that U.S. debt would trade below par value. ${ }^{324}$ Congress therefore shifted the Sinking Fund Commission's role away from open market purchases designed to bring U.S. debt to par value and charged the Commission with managing the repayment of debt.

As part of the Commission's new role in managing funds used to repay debt, Congress awarded the Sinking Fund Commission power to borrow sums up to $\$ 1$ million, with the President's approval. The Commission was to borrow these funds "from time to time . . . in anticipation of the revenues appropriated," to reimburse the loans "within a year," and to borrow at an interest rate that "shall not exceed six per centum." 325 This statute preserved executive discretion over whether or not to borrow, contained no limit on commission fees, and set only an upper limit on interest rates. ${ }^{326}$ Congress awarded the Commission a further power to borrow, with the President's approval, "sums requisite for the payment of the said instalments or parts of principal" on all "public debt" as it becomes due. ${ }^{327}$ Here, Congress did not specify a dollar amount to limit the total amount of the loan, provided that interest "shall not exceed six per centum," and allowed the Commission and President to raise these funds through new securities offerings sold at par or above. ${ }^{328}$

\footnotetext{
${ }^{321}$ Act of May 8, 1792, ch. 38, §§ 6-8, 1 Stat. 281, 282-83 (requiring the President's approbation of Commission-approved purchases).

${ }^{322} I d$. $\S 8,1$ Stat. at 283.

${ }^{323}$ See id. $\S 7$.

${ }^{324}$ See Act of Mar. 3, 1795, ch. 45, § 10, 1 Stat. 433, 435-36 (obsolete) (authorizing the Commission to issue new U.S. securities, or "stock," and requiring that "no such stock be sold under par").

${ }^{325} I d . \S 1,1$ Stat. at 433.

326 See id.

${ }^{327}$ Id. $\S 10,1$ Stat. at $435-36$.

${ }^{328} I d$.
} 
Taken as a whole, these statutes show that Congress adhered to its initial practice of delegating broad discretion to resolve important policy questions regarding borrowing and payment of debt. This debt legislation establishes that the First Congress repeatedly delegated important aspects of legislative powers to borrow money and pay the debt to the Executive Branch. In so doing, Congress plainly rejected constitutional objections to delegations of significant power to borrow money. There are no records of qualified objections suggesting that Congress lacked power to delegate important questions. Even if such objections had been raised, they were overruled by legislation delegating some of the most important policy questions facing our fledgling Republic to the Executive Branch.

\section{B. THE FIRST U.S. PATENT LAW}

Intellectual property rights were also central to the developing economy of our fledgling nation. Robert Merges recounts that " $[\mathrm{t}] \mathrm{he}$ patent system was one of the earliest instruments of economic development put in place by the young United States." ${ }_{229}$ As a result, officers who granted patents "participated in the most important job of the new national government: building the institutional infrastructure to support and promote economic activity." ${ }^{330}$ In his Report on Manufactures, Alexander Hamilton lauded the patent system's "encouragement of new inventions and discoveries." 331 Hamilton emphasized that these new inventions and discoveries ranked "among the most useful and unexceptionable of the aids, which can be given to manufactures" in the United States' developing economy. 332

\footnotetext{
${ }^{329}$ Robert P. Merges, The Hamiltonian Origins of the U.S. Patent System, and Why They Matter Today, 104 IowA L. REV. 2559, 2562 (2019); see also Hovenkamp, supra note 29, at 265 (explaining that early theories of "economic development" encouraged "construction of infrastructure and technology" by granting exclusive rights).

${ }^{330}$ Merges, supra note 329, at 2560.

${ }^{331}$ AleXander Hamilton, RePORT ON the Subject of Manufactures (1791), https://founders.archives.gov/documents/Hamilton/01-10-02-0001-0007 [hereinafter HAMILTON REPORT ON MANUFACTURES].

${ }^{332} I d$.
} 
Congress's initial patent legislation followed on the heels of the Framers' decision to include an Intellectual Property Clause in the Constitution. Article I provides that "Congress shall have Power" to "promote the Progress of Science and useful Arts, by securing for limited times to Authors and Inventors the exclusive Right to their respective Writings and Discoveries." 333 This provision was crafted against the general backdrop of the English system and the Statute of Monopolies, which permitted patents (or "letters patent") as an exception to the general prohibition against state-sanctioned monopolies. ${ }^{334}$ Now that the federal government could grant exclusive rights to national patents, there were many questions as to how Congress would go about awarding these intellectual property rights to inventors.

A major concern was how the federal government would address federal patents for inventions that already implicated conflicting patent rights at the state level. In particular, steamboat inventor John Fitch and his rival, James Rumsey, had long fought over exclusive rights to steamboat technology in the United States. ${ }^{335}$ Their earlier disputes had attracted the attention of towering political figures such as George Washington and Benjamin Franklin, ${ }^{336}$ and Fitch and Rumsey obtained a conflicting and overlapping patchwork of patent rights from state legislatures. ${ }^{337}$ On one occasion, their competing patent claims had so frustrated a state legislative committee in Pennsylvania that it wished for "a body better possessed than the legislature . . . of the means of inquiring and examining into [the] originality and merits" of the inventions. ${ }^{338}$ For Fitch and Rumsey, exclusive rights to steamboat technology in only certain states proved unsatisfactory because

\footnotetext{
333 U.S. ConsT. art. I, § 8.

${ }_{334}$ See Craig Allen Nard, Legal Forms and the Common Law of Patents, 90 B.U. L. REV. 51, 63 n.51 (2010) (noting that it is "plausible" "the Founders were aware of the Statute of Monopolies"); cf. Thomas B. Nachbar, Intellectual Property and Constitutional Norms, 104 ColuM. L. REV. 272, 330-31 (2004) (finding no "direct evidence" that the United States' Intellectual Property Clause was "drawn up in order to reproduce" English law).

335 See Edward C. Walterscheid, Priority of Invention: How the United States Came to Have a "First-to-Invent" Patent System, 23 AIPLA Q.J. 263, 270-73 (1995).

${ }^{336} I d$.

337 Id. at $271-73$.

${ }^{338} \mathrm{Id}$. at 279 (alteration in original) (quoting 2 EDMUnd B. O'CALlaGHAN, The DOCUMENTARY History OF THE STATE OF NEW YoRK 1083-84 (1849)).
} 
these limited patents would not cover "a market large enough to support extensive manufacturing." 339

Both inventors "viewed the new federal system as a means of finally resolving their priority contest." 340 Now that the Constitution enabled Congress to establish a uniform system of national patents, many expected Congress to grant national patents and resolve competing claims in private bills, ${ }^{341}$ which had been the earlier practice of state legislatures. ${ }^{342}$ But Congress never took up this role. Instead, the First Patent Act delegated critical questions regarding the issuance of patents to the Executive Branch.

1. Congress Required the Patent Board to Determine "Causes of a Very Great Magnitude." The First Congress considered markedly different mechanisms for the issuance of patents. While these mechanisms all included delegation of power to grant patents, they ranged from a modified version of the English registration system to a French examination system. ${ }^{343}$ English practice was limited and did not provide an effective way to resolve disputes between competing applicants such as Fitch and Rumsey. 344 As a result, Congress's initial bills attempted to improve on English practice ${ }^{345}$ by providing procedures and substantive rules for "interferences," or procedures in which "two pending applications ... cover the same discovery or invention." 346 Substantively, Congress considered a first-to-invent standard, which would award patent rights to "the first true inventor or . . . discoverer." 347 Procedurally, Congress

\footnotetext{
339 Kenneth W. Dobyns, The Patent Office Pony: A History of The Early Patent OFFICE 16 (1994)

340 Walterscheid, supra note 335 , at 292.

${ }^{341}$ See Proceedings in Congress During the Years 1789 and 1790, Relating to the First Patent and Copyright Laws, 22 J. PAT. OFF. Soc'Y 243, 248, 253 (1940) [hereinafter Proceedings in Congress] (recording Fitch's and Rumsey's petitions).

342 See Hovenkamp, supra note 29, at 267-68.

${ }^{343}$ See Greg Reilly, Our 19th Century Patent System, 7 IP THEORY 1, 8-9 (2017) (noting that Congress's initial bills "would have created a registration system for patents similar to that then-developing in England," but Congress ultimately opted for an examination system).

${ }_{344}$ See Walterscheid, supra note 335, at 269 ("[N]othing in the contemporaneous English common law of patents or the administrative practice dealt in any real sense with priority of invention ....").

345 Proceedings in Congress, supra note 341, at 363 (noting that the bill was "framed according to the Course of Practice in the English Patent Office").

346 Interference, BLACK's LAW DICTIONARY (2d ed. 1910).

347 Prager, supra note 32, at 162-63.
} 
contemplated having different government actors select a winner from the competing applications. After an early bill placed this determination with a jury of "twelve good and lawful men,"348 Congress moved interference proceedings to the Executive Branch. The new bill allowed "three judicious, disinterested" referees to "determine the priority of the said inventions or discoveries, and certify the same to the Secretary of State." ${ }^{449}$

When debating a motion to eliminate juries, members of a House committee recognized that interference proceedings could determine "causes of a very great magnitude." 350 Some members of the committee favored executive referees' "competen[ce] to judge" "matters of invention" and the "much greater probability of having justice done by [these] arbitrators, who are men of science." 351 (Although Congress had not yet settled on his precise role, Secretary of State Thomas Jefferson, who was also "known for [his] scientific talent," 352 was expected to play a leading role in the operation of the Patent Act.) Other members of the committee opposed the motion to eliminate juries on the ground that executive determinations would "depriv[e] the citizen of a right." ${ }^{553}$ The motion ultimately passed with the conclusion "that the right of trial by juries is not universal." 354 In the context of interference proceedings, the shift away from juries was consistent with a general understanding that initial patent grants involved privileges or public rights. Such privileges could be conferred by the Executive Branch without a jury because they were forward-looking and did not eliminate existing property rights. ${ }^{355}$

\footnotetext{
${ }^{348} I d$. at 162 (drawing quotations from a brief that Fitch filed with the Pennsylvania Assembly on September 11, 1789).

349 Proceedings in Congress, supra note 341, at 358-59 (providing for referees "mutually chosen by the parties" where possible).

3502 ANNALS OF CONG. 1413 (1790).

351 Id. at 1464 .

352 Prager, supra note 32 , at 165.

3532 ANNALS OF CONG. 1463 (1790).

${ }^{354} \mathrm{Id}$. at 1464 .

355 See, e.g., Oil States Energy Servs., LLC v. Greene’s Energy Grp., LLC, 138 S. Ct. 1365, 1373 (2018) ("This Court has recognized, and the parties do not dispute, that the decision to grant a patent is a matter involving public rights . . . "); HAMBURGER, supra note 4, at 198 (noting that "[t]he initial grant of a patent ... was a grant of a benefit or privilege" that "the executive could issue").
} 
The general understanding of patent-grant-as-privilege did not account for the significant interests of persons who held pre-existing state patents. Inventor John Fitch held steamboat patents in five states and filed objections in Congress after the committee voted to eliminate juries' role in priority determinations. ${ }^{356}$ Fitch claimed that the new federal law would expose him to "great Vexation and Expense, from Prosecutions" because it did not carve out an exception for pre-existing state patents. ${ }^{357}$ In the absence of a jury, both Fitch and his rival Rumsey asked Congress to decide their claims directly by petitioning for federal patents in private bills, and Fitch expressly grounded his petition in pre-existing state patents. ${ }^{358}$ Congress turned these petitions away and left grants of federal patents to the Executive Branch, opening the door to executive decisions that would limit important interests in state patent rights.

For reasons not disclosed by the historical record, the Senate left patent grants to executive officers and wholly eliminated the detailed interference framework considered in earlier bills. ${ }^{359}$ The Senate's amendments switched to an examination system inspired by French law. ${ }^{360}$ Under this system, original determinations of patentability rested with a Patent Board "consisting of the Secretary of State, the Secretary for the Department of War, and the Attorney General." ${ }^{61}$ Edward Walterscheid concluded that the examination system "completely removed the proposed mechanism

\footnotetext{
356 See Proceedings in Congress, supra note 341, at 361-62 (containing Fitch's "objections to striking out the clause" that would have afforded a "Trial by Jury").

${ }^{357} \mathrm{Id}$. at 362.

${ }^{358}$ See id. at 248, 253 (recounting petitions that Fitch and Rumsey presented to the House of Representatives).

359 See Walterscheid, supra note 335, at 317-18 ("[T]he Senate, for unknown reasons, completely removed any provision dealing with either caveats or mechanisms for determining priority of invention ....”).

${ }^{360}$ See id. at 290 (noting the shift from an English-style registration system to an examination system); see also Prager, supra note 32, at 165 ("The patent act, as approved on April 10, 1790, adopted a system quite close to that advocated by Franklin and Rumsey .....); $i d$. at 158-59 (quoting a June 6, 1789 letter from James Rumsey to Thomas Jefferson urging Jefferson to support the French examination system); Edward C. Walterscheid, Patents and the Jeffersonian Mythology, 29 J. MARshalL L. REV. 269, 279 (1995) [hereinafter Walterscheid, Jeffersonian Mythology] (concluding that Jefferson "quite likely approved of" the change to an examination system).

361 Walterscheid, supra note 335, at 290.
} 
for establishing priority of invention and substituted nothing in its place." ${ }^{62}$ As a result, "the Patent Act of 1790 came into being with no provision whatever concerning how priority of invention should be established." 363

The text of the Patent Act makes clear that Congress left large gaps for the Patent Board to fill. For example, Section 1 allowed "any person or persons" to petition the Patent Board for a patent. ${ }^{364}$ The Act required that petitions set forth "any useful art, manufacture, engine, machine, or device, or any improvement therein not before known or used." 365 Because this wording limited the requirement that the invention or discovery be "not before known or used" to improvements, ${ }^{366}$ it did not preclude a federal patent for many inventions that were already known or used in the states. The Act authorized a Patent Board comprised of the Secretary of State, Secretary of War, and Attorney General, "or any two of them," to consider petitions and grant patents "if they shall deem the invention or discovery sufficiently useful and important." 367 This open-ended process for initial grants of patents made no mention of interference proceedings or how the Board should determine factual questions related to patent grants.

Once the Board granted a patent, the Act bestowed substantial monopoly rights upon the patentee. The Board's initial determination of a patent's usefulness and importance was not subject to judicial review, and a patentee could bring a cause of action against anyone who infringed his or her exclusive rights and recover the infringing item along with damages awarded by a jury. ${ }^{368}$ In this action, the patent would provide "prima facie evidence" that the patentee was "the first and true inventor" or

${ }^{362} I d$.

${ }^{363}$ Id. at 290-91; accord P.J. Federico, Operation of the Patent Act of 1790, 18 J. PAT. OFF. Soc'Y 237, 248 (1936) (observing that "no provision was made" for "the possibility of several different applicants claiming a patent for the same invention").

${ }_{364}$ Patent Act of 1790, ch. 7, § 1, 1 Stat. 109, 109 (repealed 1793).

365 Id., 1 Stat at 110.

${ }^{366}$ Id.; Prager, supra note 32, at 165 (noting that Congress did not provide guidelines for patent officers "other than the undefined concept of 'invention or discovery' and their own opinion as to what is 'sufficiently useful and important").

367 Patent Act of 1790, ch. 7, § 1, 1 Stat. 109, 110.

368 Id. § 4, 1 Stat. at 111. 
"discoverer" of the patented item. ${ }^{369}$ A competing inventor could challenge the patentee's status as the "first and true inventor" only as a defense to an infringement action ${ }^{370}$ or in litigation seeking repeal of an existing patent in a district court "within one year" after its issue. ${ }^{371}$ An action to repeal a patent was risky, moreover, because the Act required an unsuccessful plaintiff to "pay all such costs as the defendant shall be put to in defending the suit." 372 The favorable presumptions for federal patentees placed them on superior legal footing and probably even bestowed outcomedeterminative advantages in close cases. These presumptions and advantages flowed directly from the Board's initial award and underscored why federal patent grants constituted "causes of a very great magnitude." 373

2. The Patent Board Created Its Own Procedure to Address Conflicting Claims to Steamboat Technology. The Patent Board soon faced key interference questions left unresolved by Congress. As recounted by one commentator, "the Patent Board was considerably disturbed when petitions for patents containing conflicting claims" to patent a steamboat "were filed by four different inventors[:] John Fitch, James Rumsey, John Stevens and Nathan Read." 374 After Fitch filed a caveat objecting to a competing application, ${ }^{375}$ the Patent Board responded ${ }^{376}$ and ultimately scheduled an interference proceeding for all applicants. ${ }^{377}$ While the Act made no mention of interference proceedings, the Patent Board was quick to fill this gap.

The steamboat dispute proved especially difficult for the Board to resolve. It implicated years of politicized contests over state patent rights, including George Washington's notable support for Rumsey in earlier state proceedings. 378 Given that Thomas Jefferson, the leading scientific expert on the Patent Board, had

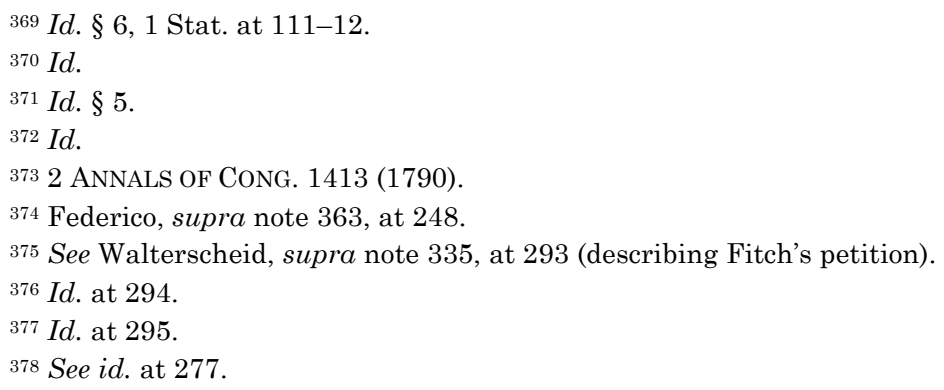


recently served as Rumsey's patent attorney in France, ${ }^{379}$ "Rumsey's agents were elated" to learn of Jefferson's role under the new Patent Act, and “[t]hey immediately removed [Rumsey's] application from Congress to the Patent Board." 380 Fitch, on the other hand, was reported to "dislike[] the [Patent] Board unqualifiedly" and continued to seek relief from Congress in addition to the Board. ${ }^{381}$ After Fitch became concerned that Rumsey's supporters spent "too much time with Jefferson, visiting privately in chambers," he requested "that a rule be established which would require all 'claims, arguments and proofs' to be committed to writing and 'that either party may have free access to them."' 382 The Board then required parties to submit "in writing to the Board a precise statement of their several inventions and of the extent thereof." 383

Perhaps due to the politically fraught nature of this dispute, the Patent Board proved reluctant to exercise its delegated power and "procrastinated" interference proceedings. ${ }^{384}$ The Board postponed its initial hearing based on a new bill that has been attributed to Thomas Jefferson and was submitted to Congress in February of 1791. ${ }^{385}$ Jefferson objected to the entire examination system because he and other board members "had insufficient time to properly carry out" their work on the Patent Board while maintaining principal offices of Secretary of State, Attorney General, and Secretary of War. ${ }^{386}$ Jefferson would later recount that he was "oppressed beyond measure" by the need to resolve weighty matters in little time and "to give crude and uninformed opinions

\footnotetext{
379 Prager, supra note 32, at 158 (recounting that Jefferson was "in effect, Rumsey's patent attorney in France").

380 Frank D. Prager, The Steam Boat Interference: 1787-1793, 40 J. PAT. OfF. Soc'y 611, 631 (1958) [hereinafter Prager, The Steam Boat Interference] (internal quotation marks omitted) (citation omitted).

${ }^{381} \mathrm{Id}$. at $631-32$.

$382 I d$. at 632 .

${ }^{383} I d$.

${ }^{384}$ Walterscheid, supra note 335 , at 294.

${ }^{385} I d$. at 294-95, 302 ("[The bill] probably was based on a draft written by Jefferson."); Thomas Jefferson, A Bill to Promote the Progress of the Useful Arts (1791), https://founders.archives.gov/documents/Jefferson/01-22-02-0322.

386 Walterscheid, supra note 335 , at 301.
} 
on rights often valuable." 387 While Jefferson's proposed amendments did not suggest rules for interference proceedings or question the constitutionality of the Board's procedural decisions, ${ }^{388}$ he did urge Congress to replace the 1790 Act's examination process with a registration system. ${ }^{389}$ Such a system would automate patent grants and potentially eliminate the need for interference proceedings. ${ }^{390}$ Congress, however, declined to act and left these matters to the Patent Board, with no indication that it disapproved of the Patent Board's interference procedures regarding the steamboat dispute. ${ }^{391}$

Records of arguments from the interference hearing show that the Board was poised to establish a substantive, first-to-file rule in order to select the winning applicant. ${ }^{392}$ Attorney General Randolph proposed a rule whereby the "earliest applicant must have the earliest patent." 393 The rule was thought to favor Rumsey, who had filed the earlier application with the Patent Board, ${ }^{394}$ but Fitch countered by noting that he "had petitioned to the Congress for an exclusive right in March 1786, long before the Patent Board was even founded." 395 This unexpected response rendered the Board members "silent for a time." 396 According to Fitch, Secretary Jefferson eventually responded "that [the Board] could make no distinction in the patents nor give one preference over another." 397

\footnotetext{
${ }^{387}$ Letter from Thomas Jefferson to Hugh Williamson (Apr. 1, 1792), https://founders.archives.gov/documents/Jefferson/01-23-02-0312.

388 See Walterscheid, Jeffersonian Mythology, supra note 360, at 292 (observing that Jefferson's bill omitted an "express provision for determining priority of invention").

389 See JEFFERSON, supra note 385.

390 See Walterscheid, Jeffersonian Mythology, supra note 360, at 297 (noting that Jefferson also asked Congress to address substantial gaps in the 1790 Act by extending its novelty requirement and establishing a nonobviousness standard); see also JEFFERSON, supra note 385 (arguing that patent rights should extend to "any new and useful art").

391 See Walterscheid, supra note 335, at 295.

392 See DoByns, supra note 339, at 27-28; Prager, The Steam Boat Interference, supra note 380, at 638-39 (describing notes of the Board's Secretary and Rumsey's agent).

${ }^{393}$ DoBYNs, supra note 339, at 27.

${ }^{394} \mathrm{Id}$.

${ }^{395} I d$.

${ }^{396} I d$.

${ }^{397}$ Id. at 27-28; see also Prager, The Steam Boat Interference, supra note 380, at 638-39 (describing notes from the Board's clerk indicating that a priority determination had "been
} 
Notes from Rumsey's representative reiterated Jefferson's refusal to decide the priority issue, as Jefferson was reported to have opined "that there are but two questions on which [the Board] can decide." 398 These questions were "(1) whether the discovery be sufficiently useful and important," and "(2) the originality" of the discovery. ${ }^{399}$

But the Board had already undertaken a hearing designed to resolve the parties' competing applications, and the relief it granted determined far more than Jefferson let on. Despite Jefferson's statement that the Board could "make no distinction in the patents," 400 the Board did just that. It later instructed the Board's clerk, Remsen, to "draft" the patents of Fitch, Rumsey, and Stevens "to make them "distinct." 401 The decision to award distinct patents seemed to track interference procedures contemplated by an earlier bill in Congress, H.R. 41, which would have allowed referees to determine how inventions "differ from each other in any material circumstance" and to certify their distinct specifications to the Secretary of State. ${ }^{402}$ The grants of distinct patents with limited specifications successfully resolved the priority disputes between Fitch, Read, and Stevens: the "species of steamboat propulsion" in Read's patent "was clearly distinct from those covered in the patent to Fitch," and "[t]he same seems to have been true with respect to whatever specific mode of steamboat propulsion was granted to Stevens." 403

These distinct patents therefore resolved competing claims for all but Rumsey and Fitch, who both obtained "overlap[ping] and

\footnotetext{
considered but not carried through"). But see Federico, supra note 363, at 383 (doubting that the Board acted "without deciding the question of priority").

398 Prager, The Steam Boat Interference, supra note 380, at 639.

399 Id.

${ }^{400}$ DoByns, supra note 339, at 27-28. This account aligns with notes from the Board's secretary indicating that a priority determination between Fitch and Rumsey had "been considered but not carried through." Prager, The Steamboat Interference, supra note 380, at 638-39.

${ }^{401}$ Prager, The Steam Boat Interference, supra note 380, at 638 (quoting ARCHIBALD DOUGlas TuRnbull, JOHn SteVEns: An AMERICAN RECORD 110 (1928)); Walterscheid, supra note 335 , at 298.

402 Proceedings in Congress, supra note 341, at 358 (referencing "An Act to promote the Progress of the useful Arts").

${ }^{403}$ Walterscheid, supra note 335, at 299.
} 
conflict[ing]" U.S. patents for "[p]ropelling boats." 404 While the precise reasons for the Board's refusal to resolve this priority dispute will probably never be known, Jefferson suggested that courts would ultimately resolve any such dispute. ${ }^{405}$ But the Board's final decision to issue patents on all of the steamboat inventions instead "broke the two men," and they never took their dispute to court. ${ }^{406}$ Further, the Board's decision discouraged inventors as well as "former and potential financiers" from pursuing steamboat technology during "the fourteen years' term of the federal patents" held by Fitch and Rumsey. ${ }^{407}$ The Board's decision, therefore, rendered both inventors' interests in existing state patents effectively worthless.

Unsurprisingly, many parties in addition to Jefferson urged Congress to address substantive and procedural rules for interferences in future amendments to the patent laws. When Congress finally took up Jefferson's proposed amendments a year later, it agreed to move to a registration system ${ }^{408}$ and considered various interference procedures. ${ }^{409}$ Members of Congress worried about the expense of creating a new department preferred a registration system that "circumscribe[d] the duties of the deciding officer within very narrow limits" and left "disputes arising from contested claims [to] devolve on referees." ${ }_{10}$ The resulting Patent Act of 1793 ultimately provided that "interfering applications . . . shall be submitted to the arbitration of three persons" for a "final" decision as to "the granting of the patent." 411 These new interference procedures stopped short, however, and failed to provide substantive rules for priority determinations. The lack of definitive

\footnotetext{
${ }^{404}$ Federico, supra note 363, at 248 n.29, 250; Walterscheid, supra note 335, at 299-300.

405 Jefferson suggested that the Board's determination was "appealable to a court and jury." Prager, The Steam Boat Interference, supra note 380, at 639 (footnote omitted). He probably referred to the Act's infringement and repeal actions, as the Act did not allow a direct appeal from the Board's decision. See id. at 639 n.142.

${ }^{406} \mathrm{Id}$. at $640-41$.

${ }^{407} I d$. at 641.

408 See Daniel Preston, The Administration and Reform of the U.S. Patent Office, 1790 1836, 5 J. EARLY REPUBLIC 331, 332, 334 (1985) (explaining the registration system).

${ }^{409}$ See 3 ANNALS OF CONG. 856 (1793) (considering ex post jury determinations or caveat procedures to resolve interferences).

${ }^{410} I d$. at 855 .

${ }^{411}$ Act of Feb. 21, 1793, ch. 11, § 9, 1 Stat. 318, 322-23 (repealed 1836).
} 
priority standards in the 1793 Act has led at least one historian to conclude that the U.S. law on priorities remained unsettled until $1836 .{ }^{412}$

\section{MADISON'S “NECESSITY” WAS Not THE MotheR OF THE IMPORTANT SUBJECTS DOCTRINE}

Not all early statutes delegated as many important questions as the First Congress's debt and patent legislation. Congress provided detailed instructions for officers operating the Mint, ${ }^{413}$ for example, and it also accompanied its capacious statutes on borrowing and repayment of debt with legislation that specified duties for imported goods in excruciating detail. ${ }^{414}$ These detailed statutes merely reflect Congress's ability to legislate with greater specificity in an area of overlapping legislative and executive powers when it chooses to do so. They do nothing to upset the constitutional baseline reflected in the debt and patent legislation discussed above. The broad delegations in key Founding-era statutes regarding debt and patents align with today's intelligible principle requirement, and they reflect a constitutional requirement that Congress need only establish some limit on executive power in legislation. When Founding-era legislation is taken as a whole, ${ }^{415}$ it does not support a decision to overrule precedent and adopt a stronger nondelegation doctrine.

Some originalists dispute the historical foundations of this baseline. They place great emphasis on a debate in the Second Congress and assert that this body recognized a stronger nondelegation doctrine when passing legislation to establish post roads in $1792 .{ }^{416}$ As explained here, however, neither a lone piece of

\footnotetext{
412 See Walterscheid, supra note 335, at 319 (noting the lack of substantive priority provisions before 1836).

${ }^{413}$ Act of April 2, 1792, ch. 16, § 18, 1 Stat. 246, 250.

${ }^{414}$ Act of Aug 10, 1790, ch. 39, § 1, 1 Stat. 180, 180 (obsolete) (specifying duties for imported goods); see also Mascott, supra note 10, at 1392 (discussing how the First "Congress often legislated with rigorous specificity").

${ }^{415}$ Cf. Mortenson \& Bagley, supra note 11, at 333 (arguing that the First Congress delegated broadly "without betraying a hint of concern that doing so might violate the Constitution").

${ }^{416}$ See, e.g., Wurman, supra note 12 , at 1506-12.
} 
legislation from 1792 nor arguments advanced on that occasion prove a historical requirement that Congress resolve all important questions. ${ }^{417}$ Objections to a delegation of power to establish post roads stymied the First Congress in 1789,418 and the Second Congress continued to debate this issue when it returned to the matter two years later. While the Bill for Establishing the Post Office and Postal Roads was before the House, Theodore Sedgwick "moved to strike out" the clause "which designated the roads" and to delegate power to establish routes to the President. ${ }^{419}$ Sedgwick's motion renewed debate over the constitutionality and expediency of a delegation to the President. With regard to constitutional concerns over delegation, Sedgwick expressed his view that the delegation under consideration would mirror Congress's practice concerning "every other subject," in which it was "sufficient that the House should establish the principle, and then leave it to the Executive to carry it into effect." 420

While several members of the House objected that the proposed delegation was unconstitutional, their arguments varied greatly. Samuel Livermore asserted that Article I, Section 8's provision empowering Congress "to establish post offices and post roads" created a congressional "duty to designate the roads" and "to establish the offices." ${ }^{421}$ Livermore's argument required Congress to determine both the very important matter of post roads and the less important matter of post offices and mirrored William Loughton Smith's earlier objection to a delegation of borrowing power. ${ }^{422}$ Sedgwick responded by comparing delegation of borrowing power to delegation of power to establish post roads. ${ }^{423}$ One might have expected James Madison, who had previously approved the delegation of borrowing power over Smith's objection, ${ }^{424}$ to favor

\footnotetext{
${ }^{417}$ The public rights implicated by the post roads debate also fail to support a ban on delegations involving private rights.

418 See MASHAW, supra note 6 , at 45.

4193 ANNALS OF CONG. 229 (1791).

${ }^{420} \mathrm{Id}$.

${ }^{421}$ Id. at 229-30; see also id. at 233 (including a similar objection by Representative Page).

422 Lloyd's Notes, supra note 21, at 1349.

${ }^{423}$ See 3 ANNALS OF CONG. 230 (1791) ("Congress ... [is] authorized not only to establish post offices and post roads, but also to borrow money; but is it understood that Congress ... [will] borrow every sum ... ?").

${ }^{424}$ See Lloyd's Notes, supra note 21, at 1350.
} 
delegation of power to establish post roads as well. But Madison switched sides in the Second Congress and opposed delegation of power to establish post roads on constitutional grounds. What could explain Madison's newfound opposition to generous delegations?

Both members of the House and scholars have questioned the sincerity of constitutional objections involving the delegation of power to select post roads. Congressmen had strong personal incentives to designate locations of post roads in locations favorable to their constituents. Representative Barnwell, for example, was "astonished" "that there should be any question respecting the constitutionality of the amendment," 425 and Sedgwick pointed out that the "gentlemen who composed" the committee "had a very important interest in establishing the directions of the post." ${ }^{26}$ Perhaps Madison himself succumbed to this temptation as well, though such action would be inconsistent with Madison's general concerns over the precedent established by Congress's early interpretations of the Constitution. ${ }^{427}$ In addition, the constitutional objection raised here was the same one that had been raised earlier with respect to borrowing. ${ }^{428}$ Borrowing money did not present the same incentives for members of Congress to pass specific legislation, and the fact that a constitutional objection was also raised in that context adds legitimacy to the constitutional objection involving post roads.

Madison raised unique constitutional objections in the debate over post roads. He did not argue that Congress had to decide all important questions or adopt Livermore's unqualified constitutional objection to the delegation of power to establish post roads and post offices. Instead, Madison asserted "that there did not appear to be any necessity for alienating the powers of the House; and that if this [alienation] should take place, it would be a violation

\footnotetext{
4253 ANNALs OF CONG. 235-36 (1791).

${ }^{426}$ Id. at 241; see CURRIE, supra note 21, at 149 (observing that "the House's zest for detail" could be attributed "more to a taste for pork"); Lawson, supra note 5, at 403 (suggesting that "postal routes" implicated "the tastiest pork").

${ }^{427}$ William Baude, Constitutional Liquidation, 71 STAN. L. REv. 1, 61 (2019) (noting Madison's concern over the precedent established by decisions respecting creation of government).

${ }^{428}$ See Lloyd's Notes, supra note 21, at 1349 (reporting Representative Smith's objection to the borrowing law).
} 
of the Constitution." 429 Madison noted that the "difficulty of accommodating the regulations to the various interests" implicated by the placement of post roads "is said to be almost impracticable." ${ }^{30}$ In Madison's view, however, these designations were capable of being "accomplished" by Congress. ${ }^{431}$ Madison objected to delegation because there was no "exigency" requiring Congress to delegate establishment of post roads to the Executive. ${ }^{432}$

Representative Sedgwick disagreed with Madison's necessity arguments. $^{433}$ But Sedgwick lost the post roads debate, and Madison's explanation offers the only understanding that can be squared with the entirety of delegation decisions approved by a majority of early Congresses. For post roads, Congress rejected a delegation to the President and designated the initial network of post roads itself. ${ }^{434}$ But refusal to delegate unnecessary matters is not the same as refusal to delegate important matters. The post roads legislation itself illustrates this point. After designating initial routes, Congress turned around and granted the Postmaster General unfettered power to enter contracts that "altered" these routes. ${ }^{435}$ Continued use of the post roads designated by Congress was therefore made contingent on the Postmaster General's decision to enter into contracts "extending the line of posts" 436 and providing that "the roads, therein designated, shall . . . be deemed and considered as post roads." 437

Given the arguments that the Constitution required Congress to make an initial designation of post roads and offices, it seems unlikely that the Postmaster General's virtually unfettered ability

\footnotetext{
4293 ANNALS OF CONG. 238-39 (1791) (emphasis added); see Lawson, supra note 12, at 3536 (identifying Madison's necessity argument).

4303 ANNALS OF CONG. 238 (1791).

${ }^{431} I d$.

${ }^{432} I d$.

${ }^{433} I d$. at 239 (containing Representative Sedgwick's assertion that "necessity could not justify the infraction of [the] Constitution").

4343 ANNALS OF CONG. 241 (1791).

${ }^{435}$ Act of Feb. 20, 1792, ch. 7, §§ 1-2, 1 Stat. 232, 233 (obsolete) ("[T] he route[] by which the mails are at present conveyed[] shall in no case be altered ... till the contracts made by the Postmaster General shall be determined.").

${ }^{436} I d . \S 2$.

${ }^{437} I d$. The Act also delegated power to determine locations of post offices despite Samuel Livermore's constitutional argument that Congress was required to specify locations of post offices alongside post roads. 3 ANNALs OF CONG. 229-30 (1791).
} 
to alter Congress's initial routes by contract would present any less of an intrusion on important subjects or Congress's legislative power to establish post roads. ${ }^{438}$ The Postmaster General's contractually designated routes appeared even more important than those initially established by statute: routes designated by the Act lasted only two years, but contracts for post roads could last up to eight years. 439 Unlike initial designation of routes, however, the Postmaster General's ability to alter existing routes may have been necessary. During the debate in the House, Benjamin Bourne observed that "[i]t will be occasionally necessary to change the route, and lay out new roads," 440 and Sedgwick asserted that the power to "establish post roads not provided for by the bill" was "indispensably necessary." 441 While Congress may have been capable of designating an initial set of roads, future legislation might have been too cumbersome to accommodate shifting populations or other dynamic factors calling for an alteration of routes. Delegation to the Executive was necessary to incorporate these important adjustments to existing post routes.

Madison and other members of the First Congress may have assumed a similar necessity when they decided to delegate borrowing power to the President. It was likely impossible for Congress to predict, in advance of final negotiations to enter into loans, the exact terms that might apply to loans adding up to the formidable sum of $\$ 14$ million. Even the rate of interest that might have been "advantageous" to the United States ${ }^{442}$ would depend on evolving market conditions and the United States' other options for avoiding the negative credit consequences that would ensue if it fell behind on loan payments. ${ }^{443}$

\footnotetext{
4383 ANNALS OF CONG. 240 (1791) (statement of Rep. Sedgwick) (arguing that provisions authorizing the Postmaster General "to establish post roads not provided for by the bill" were equally objectionable); accord Mortenson \& Bagley, supra note 11, at 353 (describing Sedgwick's view that these two provisions were both unconstitutional).

${ }^{439}$ Act of Feb. 20, 1792, ch. 7, §§ 2, 30, 1 Stat. 232-33, 239. Professor Wurman argues that Congress resolved all important questions in its initial designation of routes. Wurman, supra note 12 , at 1511 . But at most, his argument shows that the historical record is ambiguous.

4403 ANNALS OF CONG. 232 (1791).

${ }^{441} \mathrm{Id}$. at $239-40$.

442 Act of Aug. 4, 1790, ch. 34, § 2, 1 Stat. 138, 139 (obsolete).

${ }^{443}$ Riley, supra note 244, at 661 (noting that "punctuality in payment of service on a loan" was considered "the key standard of credit worthiness"). Delegations to the Sinking Fund
} 
The borrowing legislation qualifies the Second Congress's unwillingness to delegate decisions about post roads and illustrates how a constitutional line turning on necessity differs from one turning on importance. The delegation of borrowing power was undoubtedly important, leaving necessity as the key difference between willingness to delegate borrowing power and unwillingness to delegate placement of post roads. By the Second Congress's debate on post roads, representatives advanced three different possibilities for the nondelegation doctrine: (1) Congress cannot delegate great portions of enumerated legislative powers at all, ${ }^{444}$ (2) Congress can delegate great portions of enumerated legislative powers but only when necessary, ${ }^{445}$ or (3) Congress may delegate enumerated legislative powers if it "establish[es] the principle" (perhaps intelligibly?) and "leave[s] it to the Executive to carry" this principle "into effect." ${ }_{446}$ The first explanation conflicted with Congress's ultimate delegation of legislative power to designate post offices and alter post roads, as well as its earlier delegation of powers to borrow money.

This left the second and third explanations as the only constitutional arguments that were consistent with most of Congress's actions. While Madison's necessity argument may be the only explanation consistent with all of Congress's early legislation, it is unclear whether his position supports an exception to generally broad delegations or should be discounted as a one-time departure from constitutional doctrine. ${ }^{447}$ In any event, a long line of cases applying today's intelligible principle requirement incorporates a

\footnotetext{
Commission and Patent Board passed without discussion of their apparent necessity. Open market purchases reflecting financial judgment and changing market conditions necessitated delegation to the Sinking Fund Commission, and patent grants turning on scientific determinations of utility, importance, and novelty may have necessitated delegation to the Patent Board. At least one state legislature had earlier despaired of its ability to make such scientific determinations. Walterscheid, supra note 335 , at 279.

444 See 3 ANNALS OF CONG. 229 (1791) (statement of Rep. Livermore).

445 See id. at 238-39 (statement of Rep. Madison).

${ }^{446} I d$. at 229 (statement of Rep. Sedgwick).

${ }^{447}$ Arlyck, supra note 10, at 53 (explaining that members of the First Congress did not frame their debates over delegation of remission decisions in terms of necessity and that the concept of necessity is "lacking more generally" in Founding-era debates).
} 
"rule of necessity." ${ }^{448}$ Even then-Justice Rehnquist's concurrence in Benzene did not turn on importance alone: he argued that there was "no need" for Congress to delegate the question of "feasible" workplace safety standards ${ }^{449}$ because the basic determination of whether to impose a cost-benefit framework did not exceed Congress's "technical" or "expert" capacity or necessitate delegation to an "agency." ${ }^{550}$ Madison's similar necessity argument is thus but another illustration of how Founding-era delegations align with the status quo. The nondelegation doctrine recognized in the Founding Era provides no reason to invalidate swaths of broad delegations entrenched in today's regulatory statutes.

\section{The Historical Record PROvides No OCCASION to OVERTURN PRECEDENT}

The evidence unearthed in this Article provides new reasons to question the proposed leap to a stronger nondelegation doctrine. Precedent looms especially large for the future of nondelegation because the Supreme Court requires "something more than 'ambiguous historical evidence"' before it will overturn longstanding constitutional precedent. ${ }^{451}$ Proponents of a stronger nondelegation doctrine test have not met this burden. The claim that an

\footnotetext{
448 Indus. Union Dep’t v. Am. Petroleum Inst. (Benzene), 448 U.S. 607, 684-85 (1980) (Rehnquist, J., concurring).

${ }^{449} I d$. at 685 .

${ }^{450} I d$. at 675 .

${ }^{451}$ Gamble v. United States, 139 S. Ct. 1960, 1969 (2019) (quoting Welch v. Tex. Dep't of Highways \& Pub. Transp., 483 U.S. 468, 479 (1987)); see also id. at 1980, 1989 (Thomas, J., concurring) (explaining that "the historical record does not bear out my initial skepticism" or show that current doctrine is "incorrect, much less demonstrably erroneous"); William Baude, Is Originalism Our Law?, 115 CoLUM. L. REV. 2349, 2359 (2015) (noting that "most originalists" acknowledge theories "reconciling precedent and originalism"); Amy Coney Barrett, Originalism and Stare Decisis, 92 NotRe DAME L. Rev. 1921, 1933, 1937 (2017) (explaining that Justice Scalia was "willing to overrule precedent" where "the error was clear," but he would "adhere" to precedent where it "did not clearly contradict the text"); Caleb Nelson, Stare Decisis and Demonstrably Erroneous Precedents, 87 VA. L. REV. 1, 53 (2001) (arguing that the "weaker' version of stare decisis" requires adherence to "permissible" but not "demonstrably erroneous" precedent); Randy J. Kozel, Original Meaning and the Precedent Fallback, 68 VAND. L. REV. 105, 108 (2015) (advocating a "presumption of deference to judicial precedent" when evidence of "historical" meaning does not "provide a clear answer").
} 
"important-subjects conception" is "plausibly consistent" with early practice, ${ }^{452}$ or that the historical record is simply "messy," ${ }^{553}$ may be sufficient to preserve the status quo or to write upon a blank slate. It does not, however, show demonstrable error or otherwise justify a departure from longstanding precedent. Perhaps this is why Justice Scalia's approach to the nondelegation doctrine has been described as "following precedent" rather than "original meaning." 454

If any doctrine is closest to the body of generous delegations debated and approved by the First Congress, it is the intelligible principle requirement. Unlike Professors Bagley and Mortenson, who claim that there was no limit whatsoever on the substantive powers Congress could delegate to the Executive, ${ }^{455}$ early Congresses' debates over borrowing and post roads consistently recognized the need for legislation to provide at least some limit or principle to constrain the amount of power delegated to the Executive. The borrowing legislation passed after the First Congress's debate approached, and perhaps exceeded, the outer limits of delegation authorized by the intelligible principle requirement. Congress allowed the President to borrow any amount up to a $\$ 12$ million limit and required that terms of loans designed to pay off the entire national debt be "advantageous." ${ }^{456}$ Congress likewise directed the Sinking Fund Commission to repay debt through open market purchases up to par value, while allowing great latitude as to timing and amount of purchases that reflected the principle of benefitting creditors and raising the price of their stock. ${ }^{457}$ And in the Patent Act, Congress required the Patent Board to grant patents for useful, important, and (in the case of improvements) original inventions, a charge that implicitly afforded the Board discretion to determine procedures and principles governing its patent grants. ${ }^{458}$

\footnotetext{
452 Wurman, supra note 12 , at 1538.

${ }^{453} I d$. at 1494 .

${ }^{454}$ Kelley, supra note 105, at 2120.

455 See Mortenson \& Bagley, supra note 11, at 332 ("Regulatory delegations were limited only by the will and judgment of the legislature.").

${ }_{456}$ Act of Aug. 4, 1790, ch. 34, § 2, 1 Stat. 138, 139.

${ }^{457}$ Act of Aug. 12, 1790, ch. 47, 1 Stat. 186.

${ }^{458}$ Act of Apr. 10, 1790, ch. 7, §1, 1 Stat. 109, 109-10 (repealed 1793).
} 
The minimal limitations and principles contained in the debt and patent legislation also granted the Executive Branch significant discretion to resolve crucial matters of national policy. Executive officers provided the final word on key matters of borrowing, repayment, and certain aspects of patent grants that were not subject to judicial review. ${ }^{459}$ The tremendous significance ascribed to debt and patent legislation in the Founding Era is at odds with Professor Wurman's suggestion that "[p]rivate rights... are undoubtedly more important" subjects of delegation than public matters. 460 Alexander Hamilton described the borrowing and sinking fund measures he offered in "support of the Public Credit" as relating to "a matter of high importance to the honor and prosperity of the United States." 461 Members of the First Congress described borrowing as an "important power" (Smith) ${ }^{462}$ and a matter of "great trust" and "importance" (Madison). ${ }^{463}$ Patents also ranked "among the most useful . . a aids[] which can be given to manufactures" (Hamilton), ${ }^{464}$ involved causes of "great magnitude" (committee of the First Congress), ${ }^{465}$ and often implicated "valuable" rights (Jefferson). ${ }^{466}$

Nor did Congress unambiguously resolve all of the important questions implicated by debt and patent legislation. Professor Wurman claims that the Sinking Fund Commission operated under "quite specific limitations" fixed by statutory allowances forbidding purchases in excess of par value. ${ }^{467}$ But neither this statutory language nor an opinion from Chief Justice Jay resolved Hamilton and Jefferson's bitter policy dispute. They never agreed on the extent to which the Commission's below-par purchases should prop up financial markets and investors. ${ }^{468}$ Likewise, Wurman's claim that "the Patent Board never resolved the first interference case

\footnotetext{
${ }^{459}$ See id.

${ }^{460}$ Wurman, supra note 12 , at 1556.

${ }^{461}$ HAMILTON, supra note 20.

${ }^{462}$ Lloyd's Notes, supra note 21, at 1349.

${ }^{463} I d$. at 1350, 1354.

${ }^{464}$ HAMILTON REPORT ON MANUFACTURES, supra note 331.

4652 ANNALS OF CONG. 1413 (1790).

${ }^{466}$ Letter from Thomas Jefferson to Hugh Williamson, supra note 387.

${ }^{467}$ Wurman, supra note 12 , at 1547.

${ }^{468}$ See supra notes 292-313 and accompanying text.
} 
that came before it" ${ }^{469}$ misses the important policy choices left open by Congress and resolved by the Board. The Board presided over an interference hearing of its own creation, definitively resolved two of four competing patent claims as a result of this hearing, and came very close to resolving both Fitch's and Rumsey's claims by implementing a first-to-file test-the opposite of the first-to-invent test that Congress initially imposed on courts. ${ }^{40}$ At most, arguments that Congress resolved all of the truly important questions show ambiguity or a nondelegation doctrine "in the eye of the beholder." 471 They do not establish palpable conflict between original practice and governing precedent.

Finally, Professor Wurman does not seriously argue that the First Congress left only details for the President to resolve in its borrowing statutes. Instead, he falls back on the idea that Congress could not be expected to specify terms such as interest rates because these terms were "inherently unknowable in advance" and because "negotiation would be key" to their determination. ${ }^{472}$ The First Congress's act authorizing the President to borrow up to $\$ 12$ million was generally silent on interest rates and required only that terms on a large subset of loans "paying off the whole of the said foreign debt" be "advantageous." 473 While Congress had some notion of the interest rate that the President would be required to accept when taking out a loan, ${ }^{474}$ the precise interest rate was difficult and perhaps impossible to predict in legislation. But this type of unpredictability goes to necessity, which is quite different from the importance of questions delegated. As explained above, if the President borrowed $\$ 12$ million at a rate of $5 \%$ instead of $4 \%$, he would contractually obligate the United States to increase its annual interest payments by $\$ 12.86$ billion in today's dollars. ${ }^{475}$ This does not even account for the President's discretion over other terms, namely commission fees, which would also represent $3.5 \%$ to

\footnotetext{
469 Wurman, supra note 12 , at 1549.

${ }^{470}$ See supra notes 380-392 and accompanying text (discussing the interference proceeding and results); Act of Apr. 10, 1790, ch. 7, §§ 5-6, 1 Stat. 109, 111 (repealed 1836) (establishing a first-to-invent test for judicial proceedings).

471 Wurman, supra note 12 , at 1490.

$472 I d$. at 1545 .

${ }^{473}$ Act of Aug. 4, 1790, ch. 34, § 2, 1 Stat. 138, 139.

474 See, e.g., HAMILTON, supra note 20 (predicting 4\% to 5\% interest rates to Congress).

475 See supra notes 251-52.
} 
9\% of the total amount borrowed. ${ }^{476}$ The President's significant discretion over borrowing terms undoubtedly qualified as important based on its "vast 'economic and political significance" 477 and "overall impact on the economy." 478

It is difficult to grasp why the "unknowable" nature of borrowing terms should prevent debt legislation from counting as evidence that the First Congress delegated important policy questions. The major questions canon of statutory interpretation provides the opposite: unknowable yet important terms cannot be delegated by an open-ended statute. This canon requires Congress to provide clear statutory authorization before an agency can claim "to discover in a long-extant statute an unheralded power to regulate 'a significant portion of the American economy."479 Major questions cases frequently turn on matters that are unknowable in advance. For example, the Congress that enacted the Food, Drug, and Cosmetic Act did not know that harmful "drugs" would someday include tobacco products, ${ }^{480}$ and the Congress that passed relevant amendments to the Clean Air Act did not know that "air pollutants" would someday include greenhouse gases. ${ }^{481}$ Therefore, the fact that the First Congress delegated important and inherently unknowable determinations of interest rates counts as originalist evidence against arguments that the major subjects canon of statutory interpretation (or something similar) should extend to a constitutional nondelegation doctrine.

\footnotetext{
${ }^{476}$ Riley, supra note 244, at 659 tbl.1 (listing commission fees on Dutch loans to the United States).

477 Util. Air Regul. Grp. v. EPA (UARG), 573 U.S. 302, 324 (2014) (quoting FDA v. Brown \& Williamson Tobacco Corp., 529 U.S. 120, 160 (2000)).

478 U.S. Telcom Ass'n v. FCC, 855 F.3d 381, 423 (D.C. Cir. 2017) (Kavanaugh, J., dissenting from denial of petition for rehearing en banc).

479 UARG, 573 U.S. at 324 (quoting Brown \& Williamson, 529 U.S. at 159); accord Brown \& Williamson, 529 U.S. at 160 (reasoning that "Congress could not have intended to delegate" power to regulate tobacco products, a "decision of such economic and political significance ... in so cryptic a fashion").

${ }^{480}$ Brown \& Williamson, 529 U.S. at 146-47 (disclaiming any "evidence" that the enacting "Congress in 1938 even considered the applicability of the Act to tobacco products").

481 UARG, 573 U.S. at 324 (declaring that the EPA's rules "would render the statute 'unrecognizable to the Congress that designed' it" (quoting Prevention of Significant Deterioration and Title V Greenhouse Gas Tailoring Rule, 75 Fed. Reg. 31,514, 31,555 (June 3, 2010) (to be codified at 40 C.F.R. pts. 51, 52, 70, 71))).
} 
Further, if unknowability is the test (or excuses the requirement that Congress decide important questions), then there is no need for the Court to revamp the nondelegation doctrine that it has been applying for over eighty years. Delegations that satisfy the intelligible principle requirement routinely hand off matters unknowable in advance, especially in the context of the dynamic and expert determinations that pervade the administrative state. ${ }^{482}$ One need only consider Justice Scalia's approval of capacious Clean Air Act provisions in American Trucking. ${ }^{483}$ The Clean Air Act directed the EPA to set "uniform national standards" 484 for air quality by establishing pollutant levels "requisite to protect the public health" 485 and required "[a]ir quality criteria" to "reflect the latest scientific knowledge." 486 This language authorized "sweeping regulatory schemes" and empowered the EPA to set "air standards that affect the entire national economy." 487 It reflected Congress's delegation of authority to resolve unknowable matters, such as dynamic regulatory policies in which public health protections would turn on "the latest scientific knowledge." ${ }^{488}$ If the important questions test is flexible enough to accommodate the delegations authorized in early borrowing legislation and approved in American Trucking, then it is no different than the intelligible principle requirement that the Court has been applying all along. There is no need to abandon precedent to accommodate such a malleable test.

\section{CONCLUSION}

For some jurists, the search for historical evidence of a robust nondelegation doctrine has become a modern-day quest for the Holy Grail. If only originalist evidence of this nondelegation doctrine could be found, it would breathe new life into a doctrine that is "not

\footnotetext{
482 See Sullivan \& Chabot, supra note 287, at 6 (discussing agencies' role in effectuating the "dynamic expert determinations mandated by Congress").

${ }^{483}$ Whitman v. Am. Trucking Ass'ns, Inc., 531 U.S. 457 (2001).

${ }^{484} I d$. at 473.

${ }^{485} I d$. at 465 (quoting 42 U.S.C. $§ 7409(b)(1)$ ).

48642 U.S.C. $\S 7408(a)(2)$.

${ }^{487}$ American Trucking, 531 U.S. at 475.

48842 U.S.C. $\S 7408(a)(2)$.
} 
dead yet!" 489 Justice Gorsuch and like-minded members of the Supreme Court would be free to "rediscover" 490 an over 200-year-old principle that has been forgotten in recent decades. But sometimes a lack of historical evidence does not mean that something is, like the Holy Grail, a relic that is merely difficult to find. Instead, it may mean that the object one is seeking never existed-or at least that "plausible" evidence of its existence fails to establish dissonance between governing precedent and understandings of the Constitution that prevailed at the Founding.

The historical evidence unearthed in this Article shows that there is no occasion to abandon precedent, as a more accommodating nondelegation doctrine has been with us from the start. Members of the First Congress considered constitutional objections to the delegation of legislative powers. They debated both whether and at what point Congress could hand off enumerated legislative powers to the Executive Branch. The constitutional line drawn in these initial congressional debates and resulting legislation had nothing to do with the importance of the subjects to be delegated. In fact, the First Congress exceeded this line time and again by delegating important questions in debt and patent legislation.

The line recognized by early Congresses may not have been exact, but it never clearly aligned with the more rigorous tests that some originalists call for today. The overall historical record of legislation passed by early Congresses is one of broad delegation to decide important questions. Originalists looking for a more aggressive alternative to the intelligible principle requirement have embarked on a futile quest. The Founding Era does not provide the answer they seek.

\footnotetext{
489 HAMBURGER, supra note 4, at 377-78 (noting that "critics of administrative law often" defend their position with this line from a well-known "Monty Python skit").

${ }^{490}$ Lawson, supra note 12, at 9 ("In sum, the Supreme Court does not need to create a nonsubdelegation doctrine. It needs only to rediscover it.”).
} 
Georgia Law Review, Vol. 56, No. 1 [2021], Art. 3

160

GEORGIA LAW REVIEW

[Vol. 56:81 